\title{
MEXICAN IMMIGRATION TO THE UNITED STATES
}

by

Kaleigh Schwalbe

A thesis submitted to the Faculty of the University of Delaware in partial fulfillment of the requirements for the degree of Honors Bachelor of Arts in International Relations with Distinction.

Spring 2010

Copyright 2010 Kaleigh Schwalbe All Rights Reserved 


\title{
MEXICAN IMMIGRATION TO THE UNITED STATES
}

\author{
by
}

Kaleigh Schwalbe

Approved:

Mark Miller, $\mathrm{PhD}$

Professor in charge of thesis on behalf of the Advisory Committee

Approved:

Julio Carrion, $\mathrm{PhD}$

Committee member from the Department of Political Science

Approved:

Jan Blits, PhD

Committee member from the Board of Senior Thesis Readers

Approved:

Alan Fox, Ph.D.

Director, University Honors Program 


\section{TABLE OF CONTENTS}

LIST OF FIGURES .. V

ABSTRACT vi

INTRODUCTION. .1

Chapter

1 "RED LIGHT, GREEN LIGHT": THE HISTORY AND LESSONS OF THE BRACERO PROGRAM .5

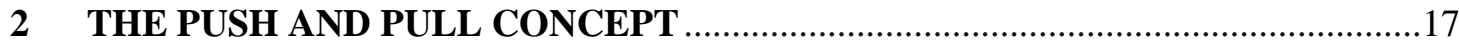

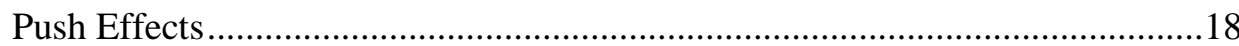

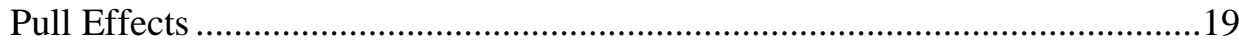

3 AN EVALUATION OF MOTIVATIONS OF LEGALITY .................................21

4 THE IMMIGRATION CONTROL AND REFORM ACT: THE CONSEQUENCES OF WISHFUL THINKING ................................................ 31

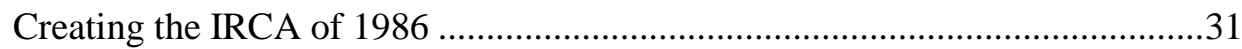

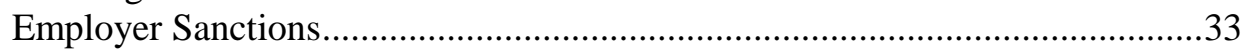

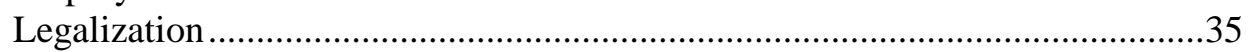

5 MISEVALUATIONS REFLECTED IN CURRENT IMMIGRATION

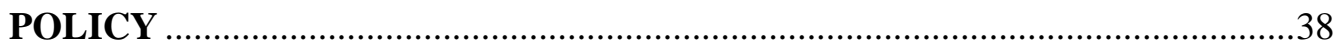

The North American Free Trade Agreement.....................................................38

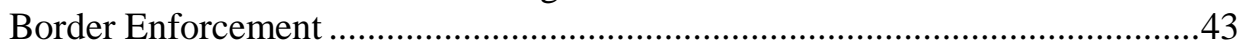

Recent US Policy: Restructuring the INS and the "Honeymoon" Period ..........47

6 IMMIGRATION AND ITS EFFECTS ON THE UNITED STATES

ECONOMY: AN ECONOMIST PERSPECTIVE...............................................50

7 RECOMMENDATIONS FOR FUTURE IMMIGRATION POLICY

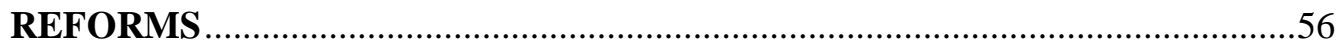

Loosening Restrictions on "Pull Factors" ......................................................57

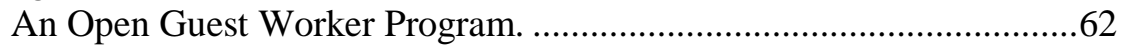

Shifting Focus to "Push" Factors .....................................................................66

iii 
CONCLUSION.

WORKS CITED

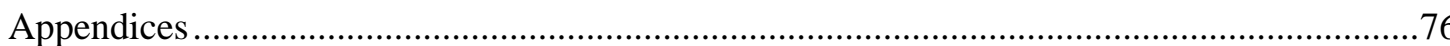

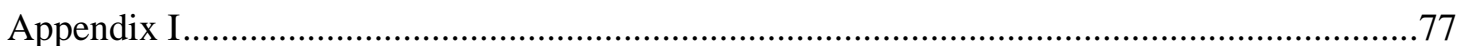

The Individuality of Immigration: Experiences through Service Learning .................77

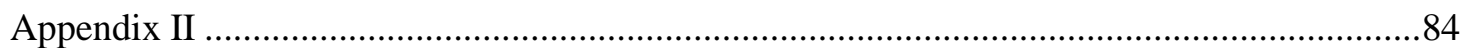

Partner's In Development, a Case Study ...................................................................84

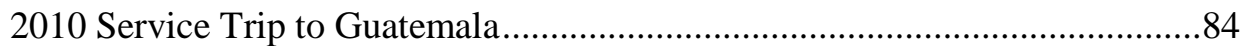

Interview with Gale Hull, President of Partner's In Development, April 2010 


\section{LIST OF FIGURES}

Figure 1. Immigrants admitted to the United States during fiscal years $1900-1994 \ldots \ldots \ldots \ldots \ldots \ldots \ldots . . .7$ 


\begin{abstract}
Mexican immigration to the United States is a controversial issue in today's political realm. Though it is the longest running labor movement in history, many Americans are under the impression that this is a current issue. In fact, there are many interesting assumptions about this movement, that many times prove to false. It is only by analyzing this issue through the context of historical and current trends, as well as through both the United States and Mexican perspectives that the issue can be fully understood.
\end{abstract}

This paper will examine the immigration movement and US policy responses to it. It will critique these policy decisions based on the success of their intended purposes, and will find that many times these policies were misdirected. Many of the shortfalls of these policies come from a lack of understanding the depth of the Mexican immigrants' incentives to immigrate to the United States.

This paper addresses these motivational gaps by reexamining the push and pull theory, and how the United States has misused this in their policy decisions. The United States is currently focusing too much on the pull motivations of immigration and not enough on the push motivations of immigration. In addition, the pull motivation side policies are being mishandled, and are far too restrictionist. By reworking the policies which address pull motivations, and by expanding and implementing policies which address the push motivations, a much more balanced immigration policy can be achieved. Specifically, the recommendations include a 
more open guest worker program, a better verification system, and a simplification of policies so that they are more easily enforceable. Furthermore, this paper advocates expanding NAFTA and developmental aid to Mexico to motivate workers to stay in their country of origin. Finally, the paper also includes my own personal experiences with immigration and development, which can be found in the appendicies. 


\section{INTRODUCTION}

Few issues in modern United States politics have generated the same amount of spark or received as much attention as the Mexican immigration movement to the United States. Fading in and out of the news media, immigration has always been a contentious issue. Even now, with the recent uproar over the Arizona Immigration Law signed in April 2010, thousands voice their opinions in protests across the nation. Even more than demonstrating the passion immigration issues create, the recent reaction to the Arizona Immigration Law shows that there is a weakness in the United States immigration policy, one that has yet to be fully solved and addressed. Hopefully the signing of this law will again reopen the immigration debate in Congress, and furthermore that the result of this debate will be a new immigration policy, one which will advance both the United States and Mexico towards future progress and prosperity.

Mexican immigration to the United States is one of the longest running labor migration movements in the world, yet why is it now such a contentious issue (Sotelo 52)? Recent changes in the movement have given it much more attention in today's news media. When Mexicans first immigrated to the United States, it was primarily to the American southwest, and their work was limited to certain industries like agriculture, mining, and railroad construction. Today we are now witnessing new destinations of this old immigration movement (Sotelo 55). Mexicans immigrants have now found jobs in many diverse sectors of the economy, and have settled and found homes in many new corners of the United States. This is largely in part to the 
expansion of social networks, which immigration relies upon. This is also in part to an expansion of the US economy, and with it an increase in labor demands from employers. When developing countries are close to countries with booming economies, migration is the inevitable result (LeMay 107).

The problem, however, is due somewhat to both changes in perception and reality, with most of the focus on illegal immigration. Illegal immigration is a problem for both the United States and Mexico. For the United States, every year millions are entering the country without record. This poses problems to both national security and regional stability. For Mexico, many of its citizens enter the United States with the hopes of finding a better living, but without the protection of legality are often mistreated. Though others will argue that illegal immigration is a problem for other reasons, those are mainly the complaints of the minority negatively affected by the movement.

This paper will define an "illegal immigrant" as a person who enters the United States without proper documentation, thereby breaking the laws of both the United States and Mexico. In older sources, the term "wetback" is used to describe this same individual, but this term is largely outdated due to its racist sentiments. At first, demographically many of these illegal immigrants were young, able bodied men coming to the United States for manual labor. However this began to shift with termination of the bracero program and the family reunification immigration provisions of the 1960 s.

The exact size of the illegal immigration movement is impossible to measure, and all statistics referring to the exact size of illegal migration are mainly 
researched estimates. Legal immigrants are easy to measure, but due to the nature of undocumented immigrants, it is difficult to find documents numbering their size and scope. The process of estimating the size of illegal immigration has even been described as "counting the uncountable" (Daniels 139). Estimates are based on different assumptions and use different sources for data calculations. Many reference census data from US and Mexico, the current population survey, registration systems, and other specialized surveys (Massey 258). Based on all of these methods, most studies estimate that there are a total of 10-12 million Mexican immigrants in the United States, half of which are estimated to be illegal, which in account for about $30 \%$ of all US immigrants (Sotelo 57). In comparison, Filipinos are the next largest immigrant group, accounting for $4.4 \%$ of all immigrants in the US (Sotelo 57). Also as another reference, immigrants as a whole, or all foreign-borns living in the United States total 37 million in number and account for $12.7 \%$ of the total US population (Sotelo 57). Comparatively, in 1910 immigrants made up 15\% of the total US population, therefore assertions that immigration is growing out of control are not well researched.

Controlling and accommodating this amount of people is no easy task, however due to its history as a country founded by immigrants, the United States is clearly capable of overcoming these hurdles. This paper will first characterize these problems, as well as the past solutions US policy has provided. The paper will then analyze these policies, point out weaknesses, and close by offering solutions for future policies yet to come.

This paper will proceed as follows; Chapter One describes the recent history of the Mexican immigration movement and evaluates US policy responses. 
Chapter Two pauses to explain the push/pull theory used to analyze different motivations for immigration, and then Chapter Three introduces and provides examples of these motivations. Chapter Four continues the history discussion through an analysis of the pivotal 1986 IRCA, and then Chapter Five follows with a discussion of the most recent and current policy decisions and institutions. Chapter Six moves forward by analyzing the affects of immigration on the US economy, which is essential to understand when advocating for more open borders. Finally, Chapter Seven puts forth my proposed solutions to the problems of past policy decisions by offering a new agenda and a comprehensive package of future reforms. Chapter Eight provides conclusions and closes the paper.

The additional appendices provide my own personal experiences with Mexican immigration. The first appendix describes how I was first introduced to the movement and how this experienced has shaped my thesis. The second appendix describes my experience abroad working with development, which has led me to many of the conclusions in this thesis. Both are supplemental but give a fuller and more personal report on Mexican immigration to the United States. 


\section{Chapter 1}

\section{“RED LIGHT, GREEN LIGHT": THE HISTORY AND LESSONS OF THE BRACERO PROGRAM}

There are many metaphors that have been used to describe immigration traffic, most referring to a "revolving door" or a "golden gate," especially when referring to the United States. However in the case of Mexican immigration to the United States, an American childhood game immediately comes to mind, one called "Red Light, Green Light." In this game, one child will stand at a distance from the others in the group. This particular child will, at random, call out either "red light" or "green light." If the child calls "green light," the others may rush forward, but when the child yells "red light," the others must immediately stop running towards him. Once a child from the reaches the child calling directions, the game is over. This game closely resembles the immigration game the United States plays with Mexico through its static immigration policy in the twentieth century. Periods of open immigration are quickly followed by sudden shifts towards restrictive policies. There is no way to tell when the United States will call "red light" and attempt to halt the flow of immigration. Especially when the very next decade, it is clear that the United States will once again call out "green light" and open their doors back up to the flow of immigrants. These inconsistencies represented by the changes in public opinion would end up causing more harm than good. 
Looking at the graph in Figure 1, the waves of immigration come in peaks and valleys. The peaks represent relatively open periods of immigration, while the valleys illustrate the sudden drop off in numbers of immigrants due to restrictionist policies. World War I in 1917 and the advent of the first bracero program in 1919 created a large peak in the graph, however a decade later the peak falls drastically during Great Depression. Following World War II, Figure 1 demonstrates another sudden increase, which experiences a drop after the 1952 INA Act. Numbers rise again, yet fall drastically after the failure to renew the second bracero program in 1964. Yet the quota system was removed in 1965, opening the U.S. back up to immigration and creating another peak in the graph. There is another small peak in the seventies, followed by the largest peak in the early eighties, a peak closely resembling the peak during World War I. Yet just as quickly as the peak rose, it falls just as drastically due to a plunge in the Mexican economy. This graph is meant to act as a road map of the peaks and depressions of Mexican immigration responding to the various ups and downs of U.S. immigration policy. 


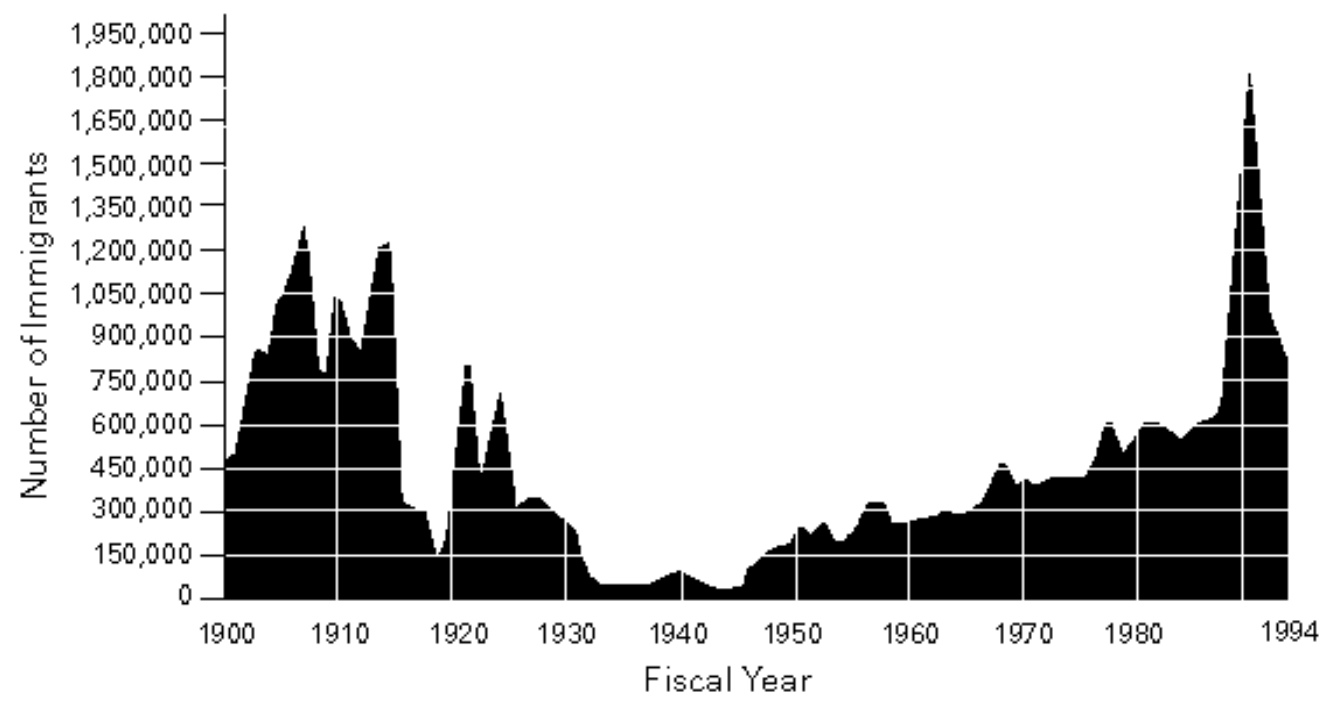

Source: U.S. Department of Justice, Immigration and Naturalization Service. Statistical yearbook of the Immigration and Naturalization Service, 1996. Washington D.C.: U.S. Government Printing Office, 1997.

Figure 1. Immigrants admitted to the United States during fiscal years 19001994. Source: http://www.migrationinformation.org/index.cfm

The tides of immigration begin in 1875 when the U.S. government passed its first immigration legislation, which prohibited the immigration of convicts and prostitutes into the United States. In 1882 a second law was enacted prohibiting, idiots, lunatics, and paupers while imposing a $\$ 0.50$ head tax (Heer 11). Immigration overall rose leading up to World War I, but fell as the war began, especially in regional immigration from Europe. Yet it was during World War I that Mexican immigration to the U.S. truly expanded into the movement it would become today. Notably, by no means did the movement begin in World War I. Indeed Mexican 
immigration to the United States is the longest running labor migration movement in the world (Sotelo 52). However the combination of several factors drove the number of Mexican immigrants up to levels which had never been witnessed before. This push began a movement that over time would expand the Mexican immigrant population towards becoming the current largest immigrant group in the United States (US Census).

As the United States became more involved in World War I, the agricultural industry became increasingly stressed. During the war, hundreds of thousands of US soldiers traveled to Europe to fight, leaving a labor shortage in their stead. In addition, thousands more poor laborers were leaving their agricultural jogs to move north to cities such as Chicago, Detroit, and New York. Industrial jobs were more attractive than agricultural labor because they paid higher wages and were available for year round employment. Finally, a dip in immigration from Europe brought on by the war also contributed to the decrease in the level of available workers (Kiser 17).

In response to this labor shortage, agricultural employers began urging the American government to temporarily allow more immigration in from the southwestern border. These commercial farmers hoped to fill the labor shortage Mexican immigrants. These immigrants appeared to be the perfect source to fill the void. Mexico was at the time in a revolution that was increasing poverty and reducing employment opportunities within their borders. Many Mexicans were looking for a way to earn money simply in order to survive. Other arguments aside, the key to the agricultural employers' argument was in linking agricultural production to national 
security. Agriculturalists maintained that the country needed food in order to feed both their troops and their country.

In response to these pressures, the US government established the first bracero program in 1917. "Bracero" is a Spanish word which translates to "day laborer," and in Mexico it is used to refer to workers that in English we describe as "hands" (Kiser 4). Through this program, Mexican immigrants were exempt from the strict immigration regulations of the 1917 Immigration Act which had been passed three months earlier. The 1917 Immigration Act, which created an eight dollar head tax and a literacy test, would have otherwise prevented many of these poor, unskilled workers from entering the country. However other restrictions were imposed to attempt to keep the movement under control. This program was meant to be temporary, just until the labor crisis ended. Also workers were only to be admitted after the Department of Labor officially certified the labor shortage claimed by the employer, and were limited to only the jobs that had been certified. However in reality, it seemed that officials tended to take employers' claims of labor shortage at "face value" rather than to investigate them fully (Ibid). Evidence later emerged to suggest that these charges of employment shortages were really intended to flood the labor market to keep wages low, yet these reports are not conclusive (Ibid, El Pueblo 11). Further restrictions included preventing dependents from following the workers, as only the workers were allowed to enter. Finally, workers were required to leave the country once they had fulfilled their contract and return to Mexico. History also indicates that this final provision was also often overlooked, with many Mexicans remaining in the country long after their original contracts expired (Ibid 4). 
The Mexican government was displeased with reports of "rampant" racial discrimination, where Mexican laborers received lower pay for doing the same types of work as United States citizens. If labor shortage was really the problem, and this program was not an attempt to lower wages in the industry, than Mexicans should be paid comparable wages. There were also reports of the US border patrol acting unfairly and causing many to try to cross illegally. Caranza (the president) began a propaganda campaign to slow the immigration movement, however despite this campaign, immigration continued unabated for the duration of the bracero program (Kiser 19).

The bracero program lasted until 1921, four years after it entered into effect. During that time, between 70,000 and 250,000 (varies upon source) braceros legally crossed the border, and as a result many important sectors became dependent upon Mexican labor (Kiser 4, 19). The logic followed that since many soldiers were now returning home, the Mexican labor force would no longer be needed.

Additionally, the movement could no longer be tied to national security, as the war had ended. However growers continued to claim a desperate need for Mexican labor, arguing that previous farm workers who had found industrial jobs would not want to move back to the lower paying, seasonal, agricultural jobs. As a result, many immigrants continued to enter the country for employment throughout the 1920s. In fact, "the termination of the first bracero program marked the beginning of an era in which American employers hired Mexican nationals in unprecedented numbers" (Kiser 5). This was perpetuated by lax enforcement of US immigration laws near the Mexican border, which enabled vast numbers to enter illegally. 
This changed with onset of the Great Depression, when opposition to the use of Mexican labor became much more prevalent and pervasive. Many letters and telegrams were sent to the US government, blaming Mexicans for American unemployment (Kiser 48). One Arizona legislature box bill claimed Mexican immigrants were "making tramps and beggars of many of our native-born citizens because of an oversupply of labor" (Kiser 50). It seemed American sentiments had turned from opening the doors to immigrants who would save the agricultural sector from devastation, to fears of excess laborers stealing jobs from Americans as the economy slowly deteriorated.

The resulting policies reflected this shift in sentiments, placing a "red light" on the immigration movement. This increase in pressure led to a significant repatriation movement of Mexican nationals during the early 1930s. These years constituted the only time period where more Mexicans left the United States than entered (Ibid 5). These mass deportations were conducted by the federal government. However many more Mexicans left the country "voluntarily" in response to pressures from state and local governments and private organizations (Kiser 5). In total, almost half a million Mexicans were repatriated during the Great Depression, and significant numbers continued to depart until the end of the 1930s (Kiser 33). The Mexican government resented this repatriation, which without notice, was forced to absorb large numbers of people while their economy was already seriously struggling.

Though extensive as the repatriation movement was, it by no means ended the use of Mexican labor in the US. Many Mexicans were not repatriated and stayed at the insistence of farmers who claimed they still desperately needed this labor source, and by the 1940s, large numbers of Mexican workers would again be entering 
the United States (Kiser 34). The "green light" was once again called out and Mexicans began to rush back into the country. Once the US entered into World War II, history began to repeat itself. Once again, the government received complaints from commercial farmers that finding labor was increasingly difficult with men leaving for the military and workers moving to higher paying jobs in defense related industries. Again the farmers linked agricultural production to homeland security, and again they appealed to the government to loosen the restrictions on the southwest border. The US government eventually conceded and in 1942, created the second bracero program.

Unlike the previous bracero program, which had been established unilaterally by the United States, the second bracero program was the result of careful negotiations with Mexico. President Roosevelt had proclaimed his Good Neighbor Policy and wanted to work cooperatively with Mexico. When the United States first approached Mexico on the idea, Mexico was initially hesitant due to the complaints of employer exploitation from the previous bracero program. The product of negotiations were contracts that specified that employers must provide adequate housing, a minimum number of working days, a "prevailing" or minimum wage, protection against discrimination, and to pay for their return to Mexico. These contracts only lasted a year, but could be renewed. In order to guarantee that employers followed their contracts, the US government agreed to serve as the formal employer and contract braceros to the individual employers.

As the war ended, it was again assumed that the program would be phased out like the first bracero program. Yet again growers stressed that past employers who had found better jobs in urban industry would not be returning to the fields. Growers 
also pointed to the fact that the United States was urging record farm production as part of its plan to assist European nations which had been devastated by the war (Kiser 69). As a result, the bracero program did not end after the war, but continued with minor changes until it was finally terminated in 1964 . Through the program, over 4.5 million Mexican workers legally entered the US for employment.

The termination of the second bracero program is an interesting political discussion. After the war, public sentiment grew increasingly against immigration. The program was almost ended in 1950, but the outbreak of the Korean conflict gave growers the support to again make the connection between labor and national security. Despite pressure from outside groups, the farmers were able to keep the program in the public interest for over twenty years. The key was that farmers acted as one political unit, pushing aside reform measures, blocking proposed amendments, and convincing Congress that renewing the program was in the national interest. Farmers and their allies consisted of labor associations, like the Imperial Valley Farmers Association, or the Trans-Pecos Cotton Association, and as lobbyists who took advantage of close ties to farming organizations like the American Farm Bureau Federation and the National Council of Farm Cooperatives. Farmers also had strong symbols on their side, as agriculture was widely believed to be the nation's basic industry, and farmers were seen as the "the nation's chosen people the guardians of its most cherished virtues, and the defenders of individual freedom, republican simplicities, and old-fashioned morality." With these attitudes and allies, the bracero program was continually renewed by Congress until the 1960s (Kiser 98-104).

In 1961, advocates of the bracero program received their final two year extension. It seemed as if the poverty of migrant farm workers was beginning to 
weigh on the national conscience. The 1961 documentary "Harvest of Shame" helped gain President Kennedy's support (Kiser 69). Through the New Frontier and Great Society programs, Kennedy and Johnson asserted that if growers were not guaranteed a fixed labor supply, then they would have to attract workers the same way as other industries, by increasing benefits until they reached the point where they would attract enough applicants to meet their needs (Kiser 69). The logic follows that if farmers only needed Mexican labor because supply was low, then raising the wage to one American workers would accept would decrease the farmers reliance on foreign labor. To enforce this policy, the Kennedy administration had the Department of Labor raise the agricultural minimum wage across the country (Kiser 111).

Farm bloc members like Senator Ellender of Louisiana began to relinquish support for an extension of the bracero program. Farmers saw the tides begin to turn, and made their final plea that if the bracero program was not renewed, that there would no longer be a legal program in place to accommodate the Mexican migration labor movement, and that Mexicans would continue to enter the country, but would now be forced to illegally. Their argument that the termination of the bracero program would increase illegal immigration largely fell on deaf ears, as there was more evidence to show that this phenomenon produced the opposite result. As a result, the Secretary of Labor deemed the bracero program "dead" in 1964.

The following year the 1965 Hart-Cellar Immigration act was passed. It consisted of a series of amendments to the 1952 Immigration and Nationality Act, one of which being the removal of the "racially based" quota system established in the 1924 Immigration Act and adjusted in 1952 (Harvard Magazine). The goal was to remove the quota system based on nationality and origin and to substitute it with 
hemispheric limits on visas issued. According to the law, a quota of 120,000 persons per year could enter the United States from the Western Hemisphere nations. Visas were issued on a first come, first served bases, yet it remained that anyone seeking employment needed approval from the Department of Labor (Heer 12). Previously Mexican workers were not subject to the visas system, so this meant that for the first time, Mexicans had to compete for visas with immigrants from other areas of Latin America and the Caribbean. These changes combined with rapid population growth and declining economic conditions in Mexico caused the numbers of undocumented workers to soar (Harvard Magazine). Visas were also based on a preference system in which labor certification and family reunification were of a higher priority. This provision for family reunification introduced a provision that would lead to a decrease in cyclical migration and an increase in permanent settlement. Now immigrants could sponsor their families and bring them with them to the United States to settle permanently, instead of returning to them each year after the agricultural season (Sotelo 53). This shift would be further reinforced by the 1986 Immigration Reform and Control Act (IRCA) through the mass legalization program. This program will be discussed further in a later section.

The bracero program provides an interesting case study for Mexican immigration to the United States. Understanding the strengths and weaknesses of this policy, which governed a large portion of the previous century, will help future and current policy makers address the migration movements of this century. Designers of the bracero program had never anticipated the extent to which the bracero program would stimulate Mexican migration. Nor did anyone at the time predicted it would spread across the country (Sotelo 53). The overwhelming response to the program to 
an extent reflects the demand from both U.S. employers and Mexican workers in this exchange. It also became clear that legal immigration, if allowed, will crowd out illegal immigration. Every time the bracero program was rescinded, illegal immigration increased. Many times, the same workers came back year after year, only one year they were able to enter legally, while the next year they were not. Once Congress responded to the demand by increasing the number of visas, border apprehensions would drop dramatically (Griswold 188). This provides support for the conclusion that when a legal option is available, workers will rationally choose this legal path to entry. When the bracero program was abolished again in 1964, illegal immigration increased again, and continues to rise to this day (Ibid). Therefore, a consistent, a more open immigration policy should be at the top of any Congressman's list for immigration reform. By offering a predictable, legal, and modestly growing labor force, this would stem the flow of illegal immigration towards legal immigration, providing the foundation for our economy to grow and prosper. 


\section{Chapter 2}

\section{THE PUSH AND PULL CONCEPT}

Before continuing the discussion of the history of the Mexican migration movement to the United States, and the lessons it has taught us, it is first important to recognize the forces operating and driving this movement, why it continues to persist. What drives these immigrants to the borders of the United States, leaving their loved

ones behind, and sometimes paying half a year's salary just to get through? There are two types of forces compelling Mexican immigration. First, there are factors pushing Mexicans out of Mexico, and second there are factors pulling Mexicans into the United States. Motivations for migration are traditionally analyzed in two ways, through "push" factors and "pull" factors. Push factors can be thought of in an economic sense as supply, as these are the factors which encourage Mexicans to leave Mexico and push them into the United States. Pull factors can therefore be thought of as the demand side, since factors are the demand created by employers for Mexican labor. These factors essentially pull or draw Mexicans from Mexico into the United States. These two factors are helpful to understand the more recent legislation, as much of the more recent legislation seems to misunderstand these factors, which often create rather opposing results than intended. Yet this analysis will start from the beginning, as to provide examples to better understand these effects and how they can be applied. 


\section{$\underline{\text { Push Effects }}$}

There are many factors pushing Mexicans across the border, but the event which triggered the sudden increase in immigration at the beginning of the century was the Mexican revolution. The Revolution begun by Francisco I. Madero in November 1910 initiated a decade of inflation, violence, and anarchy. The revolution uprooted and dispersed hundreds of thousands of people. As institutions crumbled, few people were assured personal safety. Agricultural production nearly collapsed when a labor shortage caused by people fleeing the violence left too few people to tend to crops and herds. Additionally, many landowners were not willing or able to make the heavy investments needed for agricultural production when it was not certain whether or not a revolutionary group or federal forces would suddenly seize the land. As a result, food supplies in staple crops fell drastically. From 1910 to 1918, corn production fell from $1,930,000$ to $1,975,000$ metric tons, and bean production feel from 160,000 to 107,000 metric tons. As a result food prices rose rapidly, however wages remained constant. As a result, mass inflation began to starve the rural lower class (Kiser 17).

Thus starvation initially drove many Mexican immigrants to the border in droves. These events coincided with World War I as the US lost a proportion of the working class to the military and agriculturalists lost employees to new wartime industrial jobs. Therefore, demand was met with supply, creating the first big push of immigration. Immigration continued over the decades for other reasons as well. As a developing country, the usual problems include limited economic opportunities, high birth rates, high unemployment, low wages, and widespread poverty (Kiser 7). Mexico experienced high population growth, growing from 16.5 million in 1930 to 
19.6 million in 1940 , to 25.5 million in 1950 . That is a thirty percent increase, and this coupled with the hardships brought on by the Revolution drove unemployment up drastically. Population growth also puts pressure on food supply (Kiser 133).

Many of the problems Mexico experienced as a result of the Revolution had lasting effects. Inflation continued to rise and brought up the cost of living in Mexico, despite Mexico's relatively poor standard of living. From 1939 to 1950 the cost of living index in Mexico City was 354, compared to the US which was 171, which is half the cost. Wages were also lower compared to the US. In 1949 in Mexico income was \$114 compared to the United States which was \$1453 per capita income. Higher costs and lower pay checks left many Mexicans stricken by poverty (Kiser 134).

\section{$\underline{\text { Pull Effects }}$}

When a developed country, one of the wealthiest in the world, is located on the border of a developing country, it seems natural for the citizens battling unemployment, low wages, and poor living conditions to hope to migrate to the developed country and receive better wages and more economic opportunities. It was the prospect of these opportunities that began to pull many Mexicans into the United States. As the United States became more involved in World War I, the farmers' demand for Mexican labor grew. Labor shortages in the US and labor abundance in Mexico made opening borders seem like a simple solution. In addition, technological developments in irrigation created more available farm land, making more agricultural labor necessary to keep up with production. Cotton acreage expanded from 250,000

acres in 1945 to 600,000 in 1949 (Kiser 135). As a result, farmers continually claimed 
that they had jobs that needed to be filled. Not only could the US offer more jobs, but also higher wages. Even people who found secure, full time jobs in Mexico found that they could earn much higher wages in the United States (Kiser 7).

All of these were strong incentives for the poor and, in some cases, starving Mexican workers. These strong incentives strengthened the movement, giving it a degree of immunity to events that might have otherwise been expected to drastically curtail it (Kiser 1). On several occasions, both Mexico and the United States have tried to use propaganda campaigns, policy reforms, and tighter controls to halt the migration. Yet even today, Mexicans continue to immigrate to the United States looking for better jobs and higher wages. These push and pull factors combined to make Mexican immigration one of the strongest immigration movements, and also making the Mexican population the largest immigrant group in the country.

Many times, the strength of these push and pull factors have been underestimated by policy makers, which has caused many policies to be virtually ineffective. Evidence will show that these motivations are powerful and are very difficult to control. When stricter immigration policies are created, the desires and motivations are still present. No matter whether immigrants can enter legally or not, they still have strong motivations to do so. In effect, time and time again strict immigration policy only decreases the amount of legal immigrants entering the country, not the total amount of immigrants. Immigrants then enter the country through other, illegal means. This flow of illegal Mexican immigrants will be discussed further in the following section. 


\section{Chapter 3}

\section{AN EVALUATION OF MOTIVATIONS OF LEGALITY}

Despite attempts by the United States government to control the flow of immigrants, many were able to cross the border and find jobs in the country illegally. As a result, many more immigrants entered the country than the US could control, predict, and even sometimes accommodate. Without a record, these illegal immigrants could not be protected through the bracero program, and were often exploited by their employers. Illegal immigrants were often subjected to harsher living conditions and lower wages than the legal immigrants. A trend began to emerge that wherever there were large amounts of illegal workers, usually near the borders, wages tended to be much lower. For example, in 1950 the average wage for a farm worker in California was eighty cents an hour, though in Texas it was fifty four cents an hour, and in the lower Rio Grande Valley wages were as low as twenty-five cents an hour. This forced legal immigrants who were assigned to these areas to "skip" their contracts and move farther into the country to find better paying jobs (Garcia 44).

Americans saw illegal immigrants in a very negative light. They saw them as a movement that was depressing wages, stealing jobs, and constituting a threat to national security. If there was no record of them entering the country, it was increasingly difficult to find them if a crime was committed. Mexico was displeased with the illegal immigrant situation as well. For them, that their own nationals had to

enter another country illegally in order to find a job, many times just to survive, served 
as a painful reminder of all the promises of the Revolution that had not been fulfilled (Garcia 139).

The mechanics of wetback traffic were simple. The movement centered mostly in the border cities and regions between Mexico and the United States. Most entered alone or in small groups with the assistance of a smuggler or another illegal immigrant who had made the journey before. The smuggler or "coyote" would bring the immigrants across the border, charge an average of $\$ 10-15$, and then was met by a trucker-contractor who would buy the party off of the smuggler. This trucker would then bring deliver them to a farm employer and be paid an agreed upon price per head. These people were often treated more like cattle than human beings. In order for the farmer to assure that the workers would stay until their services were no longer needed, a portion of their pay was frequently held back. Then when the work was done, neither the farmer nor the community wanted the illegal immigrant to be there any longer, and during this point in the season the number of apprehensions and deportations tended to rise very rapidly (Kiser 140).

It was very difficult for the US government to control the migrants once they were employed. Immigration officers needed warrants in order to search a farm, as it is the private property of the employer. Then when immigration officers did search a property, many of the illegal immigrants have fled before they make it out to the fields for inspections. Other times inspectors were threatened with arms or bodily harm (Kiser 151). Yet the biggest problem was that employers could not be penalized for hiring illegal immigrants until the mid-1980s. Without penalty, employers had little incentive to reject the work of illegal immigrants. Many saw this illegal immigration movement as an opportunity, and took advantage of it accordingly. 
Hubert Howe Bancroft is one such example of an illegal immigrant entrepreneur. As an "extreme racist," he welcomed both Asian and Mexican labor under certain conditions: "we want [them] for our low-grade work, and when its finished we want [them] to go home and stay there until we want [them] again" (Daniels 179). Other employers like Bancroft have also freely admitted their knowing use of illegal labor because the immigrants were willing to accept bare minimum wages and would tolerate terrible working conditions. Others explained their motivations were based on humanitarian sympathies for the starving Mexican immigrant. Yet the most pervasive theme was that they had too much difficulty finding enough legal labor, domestic and Mexican combined. Finally, some farmers claimed that they hired these immigrants unknowingly, and reasoned that it is impossible for the employer to distinguish between legal and illegal immigrants. They also argue that it should not be their job to screen these immigrants, that instead it is the responsibility of border patrol and the immigration authorities (Kiser 127).

Though border patrol is not "leak-proof," and many illegal immigrants are able to sneak through with smugglers, there are cases when the laws were purposefully broken. Often during certain times of the year, during growing seasons, enforcement becomes much more relaxed at the borders (Kiser 128). One district director in $\mathrm{El}$ Paso testified that growers place continuous pressure on Washington to have the INS issue orders to field officers to "go easy" on deportations until the crops have been harvested (Kiser 128). Another immigration officer in a northwestern district echoed this sentiment, explaining "I might state that in 1949 representatives of the Federal Employment Service asked us not to send our inspectors into the field to apprehend 'wet' Mexicans, for the purpose of deporting them, until after the emergency of 
harvesting the crops had been met. In that particular instance, we did not send the officers into the field as early as we would have otherwise (Kiser 138). In both of these accounts, these officers describe deliberate requests to turn a blind eye to the illegal immigrants in their districts.

One of the most remarkable examples of facilitating illegal immigration that I came across in my research was the "Black Bridge" in Texas. The "Black Bridge" is a railroad border entrance without customs. During growing season, the gates are continually opened and closed in order to permit the entrance of illegal immigrants. When demand for labor in El Paso rose, the gates were opened, and when demand fell, the gates were closed (Kiser 200). Therefore, it is impossible for the United States to be able to control the flow of immigrants into their borders when many times regulations are ignored and aliens are admitted freely and without record.

By relaxing immigration standards, the US government was catering to the growers. However much pressure was also placed on the US government by the workers on the farms, who in some cases had to move farther from home to find higher wages. Other citizens, some against the mistreatment of the illegal workers and others against the inherent lack of security at the borders, also demanded changes from the capital. These groups often argued that the bracero program served as a means to control the immigrant population, and without it, immigrants would continue to enter the US but have no way of doing so illegally. Thus they argued that the bracero program lowered instances of illegal immigration to the US (Kiser 120). However, there is evidence that supports this was not the case. 
Paradoxically, the steady rise in legal immigration stimulated and was accompanied by a rise in illegal immigration (Daniels 139). During both World Wars when the bracero programs were instituted the United States saw unprecedented levels of illegal workers. Therefore it would seem that the bracero programs stimulate rather than slow the rates of Mexican immigration. Every year as braceros return home, they tell others about the money they made through the program, and this encourages more to follow in subsequent years. It ended up that the number of those applying every year for the bracero program exceeded the amount of openings certified by the Secretary of labor. Miguel Claderon, the Director General of Migratory Workers in the Department of Foreign Relations from 1947 to 1960 estimated that only one out of every ten applications received a contract (Garcia 36). Those immigrants who had spent both time and money to get to the border and did not get a contract were rather reluctant to return home without their wages. Therefore many ended up illegally crossing the border into the United States. This forged the connection between the illegal and legal movements. A change in either segment of the labor force would likely have an effect up on the other.

In many studies of Mexican immigration to the US, the analysis on the movement stops here, ending on the US perspective of the issue. There are many detailed sources describing the effects of immigration upon the US, how the US responds to the movement, and how US citizens feel about immigration. Yet now it is time to analyze immigration from the perspectives of those actually crossing the border. What drives these immigrants to come to the United States legally versus illegally? Do they simply have no regard for the law, or is there more to the story? In my research, it seems that Mexicans chose to come to the United States illegally 
instead of entering legally when the barriers to entering legally become greater than the costs and consequences of entering illegally.

To illustrate this point, listed below is a list of cost analysis of the costs of entering legally and the costs of entering illegally. Both when entering legally and illegally there is first the transportation costs of getting to the border. Once the immigrant has arrived at the border, in order to enter the country legally he or she had to go through the bracero program. Thus their first stop at the border would be the recruiting office. At these offices bribery was widespread. The officers knew that a bracero contract could mean the difference between starvation and survival for many of these immigrants, making a contract a very valuable document. Additionally, as previously mentioned, perhaps only about one in ten braceros received a contract due to the Department of Labor's strict limits on the amount of contracts offered. Thus it did not take officials long to realize that since these contracts were so valuable and so difficult to obtain, they could easily make money by manipulating which immigrants received a contract. Without some sort of bribe to a local official, the chances of receiving clearance were slim (Garcia 36). For many it cost fifty pesos to get through a recruiting station, then this was followed by health checks and other procedures so that before the immigrant had even entered the United States, they had already invested fifty dollars or more. This is a substantial sum considering the poverty that many of these immigrants are trying to escape from. For some, fifty dollars could constitute half a year's income (Garcia 37). Yet it is hard to blame the officials, considering many of them receive low wages as well (Garcia 37).

To review, an immigrant may pay their way to get to the border, bribe an official or two in hopes of receiving a contract, and then since contracts are so limited, 
after all of that they may still not receive a contract. After making such an investment and receiving no returns, it is natural to consider the possibility of crossing the relative unguarded border into the country rather than returning home empty handed (Garcia 40). Yet before assumptions are made, it is important to look at the costs of crossing illegally and see which option is most likely for the immigrant.

Like the legal entrants, illegal immigrants also have costs in order to reach the border. Once at the border, crossing can be virtually free if they travel with a friend who has made the journey before, or they can pay a smuggler between $\$ 10$ and $\$ 15$ to bring them across. Illegal immigrants also tend to receive lower pay rates. The lowest rates were usually reported in the Rio Grande Valley, where there was the highest concentration of illegal immigrant workers. These workers were not protected by the "prevailing" or minimum wage laws put in place by the bracero program contracts. Without these contracts, the immigrants were also not guaranteed constant employment, or fair hours and living conditions. Some immigrants later reported working over fifteen hour days (Garcia 45). In addition, one farmer from Brownsville expressed that many Mexican immigrants there were "living in shacks I wouldn't put a horse in" (Kiser 149). Sometimes Mexican immigrants were found living in crowded, filthy wooden shacks with little ventilation and without bathing facilities (Garcia 45). These types of living conditions encourage the spread of diseases and are a serious health concern. However these illegal immigrants had little say in the matter. If they were unhappy with their situation, without a contract there was nothing to do but either stay or walk away. Some employers even went so far as to threaten workers with deportations, claiming they would call the immigration officers if the immigrants did not work the hours that the employer desired (Kiser 127). 
It would seem that these difficult conditions would turn away many workers. However, for many a job with long hours and low wages was much more welcome than no job at all, especially if they are living on a subsistence level. Many immigrants were fleeing conditions of unemployment and wages even lower than the lowest wages offered by US employers. Also many Mexicans were generally accustomed to a much lower standard of living, so perhaps the lower conditions, maybe not the worst conditions, were not as much of a disincentive for the illegal workers (Kiser 127).

Yet the question remains, why didn't Mexico do more to stop the mistreatment of their nationals, whether legal or not? The government knew about the problems their citizens were facing abroad, as some legal braceros reported to Mexican consuls for help (Garcia 45). Mexico did in fact make attempts to solve these problems, yet it had little bargaining power. At one point, treatment in Texas was so poor that Mexico refused to allow any braceros to be contracted to any employer in the state. The El Paso Incident shortly followed this discontinuance in 1948, where officials at the border ignored the US Department of States' request to withhold bracero contracts to Texan farmers at the insistence of the Mexican government. These border officials began to unilaterally recruit workers from Mexico, creating a massive break with thousands of immigrants rushing the border. When these immigrants reached El Paso, immigration officials seized them, placed them under arrest, and then proceeded to hand them over to the Texas Employment commission. As a result, US immigration officials facilitated the admittance of 5,000 illegal workers (Garcia 75). 
It also may have been easy for the Mexican government to occasionally turn a blind eye considering how much the bracero program helped the Mexican economy. Not only did the United States provide an outlet for their excess labor, relieving pressure on the weak job market and limited food supply, but also the remittances sent back to Mexico helped spur development. In 1952 it was estimated that bracero remittances totaled $\$ 670$ million, where other sources during the 1950s ranged from $\$ 22$ to $\$ 120$ million annually (Garcia 58). These remittances, along with border transactions, tourism not only aided Mexican development, but also helped reduce Mexico's trade deficit with the United States (Garcia 58).

Thus after the major costs of each option have been realized, the question remains: do the barriers and costs of entering legally outweigh the costs and hardships of entering illegally. It is clear from the cost analysis that this answer is not always yes, very often it is easier to enter illegally than to enter legally. Though when entering illegally, the immigrant may perhaps be treated slightly more poorly, receive lower wages and lack the protection of a contract, it may be better than waiting for weeks in line and paying bribes for a contract that may never be issued. Some veterans of the system even went so far as to say the contracts were meaningless for them. One immigrant confessed to Galarza "Eight times I have been in the United States, four times as a wetback and four times as a bracero... The new ones without any experience have the illusion of the contract, but not me. When you come as a bracero it passes the same as when you come as a wetback" (Garcia 55). This immigrant had similar wages and treatment with and without a bracero contract. Therefore this particular immigrant would definitely find it more beneficial to enter illegally rather than legally through the bracero program. There are several more 
examples similar to this one, of Mexicans who would have preferred to enter the United States legally, yet were discouraged by the way the bracero system operated, because "entering illegally proved tom any an easier and far less expensive way to come to the United States" (Garcia 37-38). Therefore, when the barriers to entering legally exceed the risks and costs of entering illegally, research indicates that Mexican immigrants will chose the route of least resistance and end up entering illegally. This is a crucial factor to consider when making policy to control this movement. When creating policy, it is important to make the barriers of entering legally lower than the costs of entering illegally, or else the flow of illegal immigration will continue. 


\section{Chapter 4}

\section{THE IMMIGRATION CONTROL AND REFORM ACT: THE CONSEQUENCES OF WISHFUL THINKING}

\section{Creating the IRCA of 1986}

During the 1970s, the world's growing economic and political interdependence, in conjunction with advances in transportation and communication made the United States more accessible to immigrants than ever before (LeMay 18). As a result, the number of immigrants entering the United States during this time period rose dramatically. The influx from Mexico in particular was also the result of the unanticipated consequence of the termination of the bracero program in the previous decade (Ibid 21). Additionally, employers in other sectors of the economy outside agriculture, including construction, services and manufacturing, began hiring Mexican workers in greater numbers (Sotelo 53). This led to a diversification of the labor force, and with it, a greater demand or pull for Mexican workers. Legal immigration from Mexico had grown form about 60,000 in the 1940s to 1.6 million by 1980, making Mexicans the largest immigrant group in the United States (Daniels 180, Sotelo 53). Yet along with this growth in immigration came a growing sense of crisis. Public opinion reflected widespread dissatisfaction through mass media, general public opinion polls, and within the government (LeMay 25). There was a growing sense that immigration policy was not under control. The traditional fear that immigrants would "steal" jobs from Americans was heightened by the severe 
"stagflation" of the economy between 1975 and 1983, which produced double-digit inflation, soaring interest rates, and the highest unemployment figures since the Great Depression (Daniels 220). The country desired new policies from the government that would meet this new challenge and slow the flow of migrants to the US.

In response to these fears, President Carter and Congress in 1978 created the Select Commission on Immigration and Refugee Policy (SCIRP) which would study the issue of immigration. The Commission opened in May of 1979, and submitted their final report of four hundred and fifty pages in 1981 (LeMay 34). The report recommended "closing the back door" to undocumented immigration, while opening the "front door" to more legal immigration. They maintained that immigration in fact served the national interest, yet also recognized the nations "limited ability to absorb large numbers effectively." In regards to future reforms, the Commission placed a focus on family reunification, yet its clear stress was in recommending the enforcement of existing immigration laws through the imposition of employer sanctions, increased law enforcement, an amnesty program, and a restructuring of legal immigration (LeMay 35-36). Though this report was submitted in 1981, it would not be until 1986 that many of these recommendations would be passed through Congress into law.

There were many drafts of the bill of what would become the Immigration Reform and Control Act of 1986. The final bill itself consisted of a series of compromises, resulting in a bill that the Washington Post would describe not as the perfect bill but as "the least imperfect bill we will ever have before us" (Washington Post, 16 October 1986, A5; LeMay 1987, 146)/(LeMay 55). The primary purpose of the law was to make it difficult for undocumented immigrants to remain in the United 
States. Employer sanctions were created, which made it illegal for an employer to knowingly hire or recruit any illegal immigrant. This law for the first time proposed a punishment not only for any Mexicans breaking the law, but to Americans as well. Employers were responsible for and required to examine their employees' documents, and to only hire them if they were legal residents. If an employer was caught breaking this law, they were fined $\$ 250$ for their first offense, and up to $\$ 10,000$ per immigrant for their third offense. The law increased penalties on anyone caught smuggling illegal immigrants into the US. To ease the transition, Congress also allocated $\$ 35$ million for an emergency immigration fund for cases like the 1980 boat-lift from Cuba (LeMay 55-57)

The other important provision of this law was one time, mass legalization program. This provision provided temporary resident status for aliens who had resided continuously in the US since before January 1, 1982. These temporary residents were then allowed to become permanent residents after eighteen months if they could show a minimal understanding of English and US civics. This provision resulted in the legalization of 2.7 million aliens (Castles 183). Again to alleviate some of the burden from the state governments, the federal government appropriated $\$ 1$ billion per year for four years to reimburse states for public assistance programs like health and education (LeMay 55-57).

\section{Employer Sanctions}

The 1986 IRCA states that it is illegally for an employer to "knowingly" hire an illegal immigrant, and that a graduated civil fine and criminal penalties will be

enforced upon convicted employers. Employers may use either a social security card, 
birth certificate, or driver's license from any US state. Since most immigrants who come to the United States come to work, the intention was that this policy would eliminate illegal immigration. However in order for this to be the result, the government relied on several assumptions. It assumes that illegal immigrants will not have access to proper documentation, whether it is valid or forged, and that employers will be able to tell the difference. It also assumes that the policy will be perfectly or well enforced, which will discourage employers from hiring illegal migrants. Unfortunately, these assumptions proved to be flawed.

The IRCA required employers to fill out an I-9 form for each new employee in order to prove the employee's employment eligibility. However, many of these verification documents could be easily forged or fraudulently obtained. Employers were not responsible for determining if these documents were real, they were only responsible for "knowingly" hiring illegal workers, and therefore could not be persecuted for hiring immigrants with false documents. As a result, many illegal immigrants were hired through the use of false documents. The Commission for Immigration Reform concluded in 1994 that the employer sanctions system adopted in 1986 had failed because so many unauthorized foreign workers could simply present false documents to employers (Castles 183).

Enforcement of the employer sanctions for employers who knowingly or purposefully hired illegal migrants proved equally difficult. First of all, the INS was not given legal authority to enter an employer's property without permission from the employer. If an employer knowingly had illegal migrants, he would obviously not allow the agent onto his property, thus making the law impossible to enforce (Daniels 225). Even when INS agents were allowed onto the property, farms were so large that 
illegal immigrants usually had time to hide before they were found. And if by chance an INS agent successfully found an illegal immigrant on the property, insufficient personnel, poor coordination between various agencies, and inadequate judicial follow up allowed many employers to go unpunished (Castles 182).

The overall record for employment sanctions enforcement is rather weak. In 1999, the US government announced that it would suspend enforcement of these sanctions. As a result, INS employer investigations dropped drastically from 7,537 cases completed and 17,552 arrests in 1997 to 3,898 cases completed and 2,849 arrests in 1999 (Castles 183). Finally, after the terrorist attacks on September 11, 2001, inspections shifted their focus from worksites to airports and other areas with greater security relevance (Castles 183). Due to these two major shortfalls, a lack of clear and adequate governmental enforcement and a lack of a document verification system, a program that was in theory a helpful tool against illegal immigration proved to be virtually useless in slowing the flow of illegal immigrants. If policy makers take these lessons and address these issues, the system of employer sanctions does have the potential to reduce the number of illegal immigrants who enter the workforce in the US.

\section{$\underline{\text { Legalization }}$}

The IRCA provided that all immigrants residing in the US before January 1, 1982 were given the opportunity to adjust their status to that of permanent legal resident. In addition, the alien would need demonstrate a proficiency of English, maintain uninterrupted employment, paid taxes, and to have a clean criminal record (Castles 186). The act also created a new legal status, called temporary resident status. 
All immigrants who had resided continuously in the United States in an unlawful status since before January 1, 1982 were to be granted the opportunity for achieving this new status. In addition, the alien would have to pay a fee set by the attorney general of $\$ 185$ (Heer 198). These fees and requirements created the notion of "earned" legalization (Castles 186). In total, approximately 2.7 million previously undocumented aliens gained legal status through this provision (Castles 185).

The intent of this provision was that after the illegal migrants in the US were legalized, the INS could then spend more of its efforts on preventing new aliens from entering the country, rather than diluting their efforts on finding those already in the country (LeMay 73). Therefore, the overall intended effect of the provision, like that of the employer sanction provision, was to help decrease illegal immigration to the US. However, again like employer sanctions, this proved not to be the case. In fact, this provision may have actually increased the number of undocumented aliens immigrating to the US. Legalization provides more freedom of movement, thereby allowing these newly legalized aliens to seek out different, and perhaps better, jobs. They were then free to travel across state lines without fear of apprehension (Sotelo 54). As a result, this decreased the supply of labor in the agricultural sector, thereby increasing employer demand in those sectors all over again.

Another argument against legalization was that it rewards those who broke the law, while penalizing those who obeyed the law (Pastor 130). This may have led to a change in incentives for illegal immigrants. The mass legalizations, though at the time considered a one-time deal, created a precedent, and with it the possibility that it could happen again. This may have given future illegal immigrants 
the idea that if they stayed in the United States long enough, that they too may be granted this temporary legal status.

However, by far the most important overall side effect of the legalization provision of the IRCA was its contribution to the shift it from a cyclical to a more permanent migration pattern. Once these new aliens were legalized, they were then allowed to sponsor their families to come to the United States, further increasing the immigrant population within the US (Coates 107). This law also provided new incentives that would motivate immigrants to remain in the United States rather than to return home. First, now that they were legalized they could bring their families with them to the United States, thereby removing one primary reason for their return to Mexico. Second, by increasing by millions the amount of immigrants in the country through the legalization program and through the immigration of family members, this greatly increased the immigrant network which both legal and illegal immigration relied on (Martin 247). These networks are what draw new immigrants into the country, and what give them support for finding employment once they arrive. Therefore, instead of discouraging and limiting the amount of illegal immigration into the country, the IRCA in fact provided additional avenues for doing so. Through the IRCA, the "fundamental rules of the game had changed" (Coates 107). A shift began from seasonal, circular migration pattern of the past towards one of permanent settlement. The increases to border enforcement of the following decades would further impact this phenomenon. Yet it is clear that the IRCA backfired, and its results were clearly the opposite of its desired intents. 


\section{Chapter 5}

\section{MISEVALUATIONS REFLECTED IN CURRENT IMMIGRATION POLICY}

The major events of the 1990s in regards to immigration included the formation and entry into force of NAFTA in 1994, increases in border enforcement in the 1990s, the restructuring of the INS in 2002 into the Department of Homeland Security, and the Honeymoon period between US and Mexico that although important to note, unfortunately yielded few changes for immigration policy. These events shaped the immigration movements for these decades; some had effects that opposed their intended purposes, and others whose full effects are yet to be realized.

\section{The North American Free Trade Agreement}

Following the IRCA of 1986, the next major US policy decision to have a significant effect on Mexican immigration was the creation of the North American Free Trade Agreement (NAFTA). This was not just an US policy decision, but one from Mexico and Canada as well. NAFTA created a trading agreement between Mexico, Canada, and the United States which would make trade between these countries easier and less costly. NAFTA eliminated all tariff and nontariff (ie. quotas) barriers to trade and called for equal treatment in each country for all goods and services created within these countries. Countries were also committed to not erecting new obstacles to trade after it's signing and committed to extending to NAFTA 
partners any special trade benefits that the countries shared with others outside the NAFTA agreement.

During the negotiations which predated the instatement of NAFTA in 1994, immigration issues were purposefully avoided since the US' and Mexico's viewpoints were so different (Miller 28). However, both countries signed the treaty with the understanding that NAFTA may indirectly decrease Mexican immigration to the United States. The idea was that with NAFTA would come increased trade liberalization, which would create a better climate for investment in Mexico, leading to the creation of more jobs in Mexico. In this model, Mexicans would have access to more jobs in their own countries and would be less motivated to immigrate to the United States.

NAFTA has seen many successes since entering into force in 1994. Overall, both sides of the Mexican-American border have benefited from the agreement (Labastida-Tovar). Between 1994 and 2008, Mexico's non-oil exports have increased four times over and the stock of foreign investment is fourteen times higher (Coates 103). In the US, overall exports to NAFTA partners increased 104\% between 1994 and 2000, while trade their other partners combined only grew half as fast (Ibid). However despite many of NAFTAs successes, there are still some concerns that growth has not been as large as expected, and that there have even been some negative effects from the agreement.

Americans often complain of jobs being shipped abroad to Mexico. However, Mexico is experiencing this same difficulty. Just as factories from the US are moved to Mexico, those same jobs also travel to Asia to countries with even lower 
labor costs than Mexico. Mexican workers are experiencing this same loss of industrial jobs. Also, many of the factory jobs that did move to Mexico are located in the maquiladora sector right across the border. While the manufacturing sector in Mexico as a whole grew by 2.7 million jobs since NAFTA, 800,000 were in these maquiladora plants. Wages in these plants are $40 \%$ lower than in the traditional manufacturing sector, and since inputs for these factories are generated abroad, the potential for these factories to generate new jobs in input sectors is limited (Coates $105)$.

Additionally, instead of decreasing wage differentials between the US and Mexico, which is regarded as a primary motivator for immigration, income disparity between the two countries actually grew by $10.6 \%$ during the first ten years of NAFA (Ibid 103). In the agricultural sector specifically, the average wage fell from 535 to 483 pesos per month. Employment in the agricultural sector has also dropped steadily, falling from 22.6 million in 1990 to 15.8 million by 2000 . Those most affected were the corn producers, with a loss of over one million jobs. This can be attributed to the annual \$20,000 farm subsidy for American farms, while in Mexico it is only \$720. As a result, the large corporate farms in the US that receive the largest subsidies crowd out even the most well-financed smaller producers, making it impossible for them to compete (Ibid 106). Another important note is that corn is the center of the Mexican diet and has been a staple crop for the country, yet now Mexico has become a net importer of corn. While the extra income from the export of cash crops helps alleviate the trade difference, the revenue goes to those more likely to immigrate to the US for better jobs, whereas the rural farming communities which rely on corn have been left devastated (Ibid). If NAFTA can be adjusted to make the inequalities it generates less 
damaging to those vulnerable populations, it would provide significant and beneficial effects (Ibid 111).

Due to these negative economic effects from NAFTA, many would argue that NAFTA, in regards to immigration, has become yet another failed policy where the intents of the policy were remarkably different from the results. However those that follow this school have been too assuming and have not been patient. NAFTA has a great deal of potential that has not yet been given the opportunity to be fully realized. The agreement created sweeping changes in the economies of its members, changes that are still being addressed and adjusted to. An economist Phillip Martin makes a compelling case for the "migration hump." Martin argues that indeed in the long run, migration from Mexico will decrease, but in the short run the US and Mexico will experience a migration hump, or a temporary increase in the migration above the trend it will settle upon. The push factors of migration would be strengthened in the short term by the decline in the Mexican corn sector when confronted with cheaper corn imports from the United States. As a result, the US would require more labor to keep up with the new demand, and would require more field workers, thereby increasing pull factors in the short term as well (Martin 231). However, as countries specialize and find their trade balance and as Mexico begins to develop more quickly the trend will be reduced. Policy makers must be aware that this pulse of migration is short term, and should not use it as an excuse to slow the implementation of NAFTA, since doing so would also slow the development necessary to eventually reduce migration in the long run (Martin 33). To resist such measures would seem counter-intuitive to a politician, how can allowing migration 
lead to less migration? It is by looking at the short term and long term effects that this solution becomes clear.

Just as Martin predicted, Mexican immigration in the United States soared after the implementation of NAFTA (Miller 29). Therefore it is now important for politicians to allow the migration influx for the present with the assumption that it will decrease to a steady and more predictable flow over the long run. The United States just needs to make it over this hump, and once the economy has the opportunity to adjust to the changes and opportunities that NAFTA allows, immigration will adjust and settle as well.

The European integration project brought about through the formation of the European Union (EU) acts as an example of the "migration hump" theory in action. Under the rules of accession, the core fifteen member-states could chose to temporarily block the freedom to labor mobility provision from a new member state for up to seven years. Some countries chose this option, but others like the United Kingdom, Ireland, and Sweden chose not to, and substantial migration resulted. Later on other states like Spain and Portugal modeled these leading countries and repealed their temporary bars on migration. Overall, the economy of the EU benefited from the reduction in migration laws, and the measure also helped to reduce the socioeconomic gap between the countries of the EU (Miller 31). This does not mean that these countries' economic levels were lowered; instead they helped raise the economic level of their partners. Eventually, the migration flows in Europe balanced out. It did not take perfect equality between the countries to create this balance, income and unemployment gaps do not have to disappear to slow migration, these gaps just need to decrease to a certain point. Where this point lies is difficult to determine, and it is 
different with every country. For example the per capita income gap between Portugal and France and between Greece and Germany is about one to four, and unemployment rates are at least twice as high in the southern EU member states, yet migration has balanced (Martin 25).

Thus the migration hump theory, as tested by the European Union, should serve as comforting evidence to those worried about the influx in immigration from Mexico to the United States. Once the economic conditions in Mexico have risen to a level that is not quite so drastic from the level of the United States, indeed once this gap is decreased, migration will slow as it did in Europe. The United States should take this lesson from Europe and take advantage of NAFTA, using it to help decrease the economic gap between the US and Mexico, thereby decreasing the flow of migration over the long run. Therefore although NAFTA has not been as successful as many had hoped in the short run, given time and patience the agreement will surely lead to many future successes.

\section{Border Enforcement}

Despite the efforts of NAFTA in the 1990s to eliminate the economic borders between the United States and Mexico, policies of the 2000s seemed to focus mainly on building physical and legislative borders between the United States and Mexico. In the early 1990s, President Bill Clinton and Attorney General Janet Reno began the project of militarized enforcement along the U.S.-Mexico border. Between 1993 and 2000, the United States more than doubled the size of its border patrol, more than tripled the size of its budget for the INS, and used more funds to build more fences along the 2,000 mile Mexican border than ever before (Pastor 120). 
Specifically in 1996, the United States adopted another immigration law that strengthened the Border Patrol, expanded detention facilities for aliens, expedited deportation, and expedited deportation of criminal aliens (Miller 29).

The intent of these barriers was to prevent immigration through the policy of "deterrence" (Cornelius 2). The goal was to discourage or scare aliens away from crossing the border illegally. By making it more difficult to cross illegally, it directly increased the costs of immigrating illegally. Not only was the threat of apprehension greater, but these efforts closed off the traditional routes that led to cities, pushing the migrants into the dessert in order to cross the border. These routes were much more dangerous, further increasing illegal migration costs. Another option was to cross using "coyotes," or Americans who were paid by the illegal aliens to smuggle them across the border. The increase in border enforcement made it more difficult for the coyotes to smuggle the immigrants into the country, and thus they would need to increase their fees, thereby increasing the costs of illegal immigration and decreasing the incentives to doing so. From 2000 to 2001 alone the cost of coyote fees jumped from $\$ 650$ to $\$ 800$ (Pastor 120). Therefore in theory, increasing border patrol and building more fences should deter more illegal aliens from entering the country, thereby reaching the end goal of having less illegal aliens within the United State's borders.

However, like many immigration control policies, the results run counter to the intent. Despite these attempts to tighten the border, the overall number of legal immigrants in the United States continued to increase throughout the 1990s, and it although illegal immigration is impossible to measure, it is expected that this number rose as well (Massey 285). It is clear that these policies truly underestimated the 
strengths of the motivations for these immigrants to come to the United States, border or no border. As previously mentioned, with the increased border patrol in cities and more accessible and traditional border crossing sites, immigrants were forced to cross in more dangerous locations through the desert and the mountains. When crossing at these points, immigrants risk dehydration in the desert or freezing in the mountains, even shootings by ranchers at the borders (Pastor 120). Between 1995 and 2006 there were over 3,700 known migrant fatalities due to unauthorized border crossings (Cornelius 3). This is a sure sign that this policy radically underestimates the strengths of the immigrants' motivations for coming to the United States.

A case study of research conducted by Fuentes and his team in the Tiacuitapeno and Animeno states in year illustrates how this policy fails to address the strength of immigrant motivations. This case shows that it immigrants were not crossing without knowing the dangers they when crossing, but in fact knowingly risked their lives to come to the United States. Of the Tiacuitapeno and Animeno migrants who had crossed without documentation, seventy-five percent responded that they were aware of the recent border buildup before crossing. However, 80.2 percent of those migrants reported that this knowledge of the border build-up did not influence their decision to migrate (Fuentes 55). The fact that these immigrants are willingly risking their lives to immigrate to the United States reflects the strength of their motivations, and more importantly, reflects how important it is for US policy makers to understand and take these motivations into consideration when creating immigration laws. If these motivations are not understood or considered, the policies will likely fail just as the border enforcement measures have failed to stop the flow of illegal immigration. 
Another important aspect of this policy to consider is not only how it affects (or does not affect) the behavior of illegal immigrants risking their lives to enter the United States, but also how this policy affects illegal immigrants already inside the US' borders. An economist from the Board of Governors of the Federal Reserve System, Andrei Zlate, released a new study this March on the effects of border enforcement on migration from the perspective of those migrants already in the United States. In the model he proposes, the incentive to emigrate depends on the expectation of future earnings at the destination relative to the country of origin, on the perceived sunk costs of emigration, and on the return rate of immigrant labor. The expectation of future earnings, as previously discussed, is a strong motivator for immigration due to the wage differentials between the US and Mexico. Taking this wage differential to be a relatively constant phenomenon for the time being, sunk costs become an important motivator. These sunk costs are the costs of immigrating, which are largely reflected and altered through the tightening US immigration policy and border enforcement. Specifically, it is these sunk costs will not only have an effect on the decisions of those immigrants entering the US, but also on those already in the US. Traditionally, immigrants came to the United States to find work for the agricultural season and then left when the season was over. However border enforcement breaks this pattern. Those illegal immigrants who have made it into the United States under loser border patrols will be resistant to leave the United States as the border patrols tighten. Not only to they risk apprehension returning home, but also their return to the United States for the following agricultural season will be much more difficult. It would instead be easier to stay in the Untied States until US immigration policy, as it 
is common for US immigration policy to do, changes again by loosening restrictions along the border.

The tightening at the border also works against the development efforts of NAFTA and prolongs the immigration hump. If the wall was perfectly successful and legalization measures were so difficult as to nearly halt immigration to the United States from Mexico, it would end up hurting both countries profoundly. For Mexico, the US would no longer be an outlet for its surplus labor, creating unemployment and instability south of the border that would likely disrupt oil imports and NAFTA based trade. In the United States, food prices would rise, the period of cheap construction would end, further disrupting the already troubled hosing sector (Coates 110). The economic effects of immigration in general will be discussed later in this paper, however it is important to touch upon this point now in order to illustrate that although Americans may not notice the gains of immigration now, if it was seriously reduced then it would be very noticeable.

\section{Recent US Policy: Restructuring the INS and the "Honeymoon" Period}

When the terrorists struck the World Trade Center on September 11, 2001, the United States began to view immigration in a new way. For the moment, immigration concerns shifted from job security to homeland security. In response, in 2002 Congress passed the Homeland Security Act, establishing the Department of Homeland Security. The act abolished the INS and reallocated its jurisdiction and functions into the new Department. The administration of immigration services, specifically permanent residence, naturalization, as asylum became the responsibility

of the U.S. Citizenship and Immigration Services. Enforcement became the 
responsibility of the U.S. Immigration and Customs Enforcement. Whereas border functions and responsibilities were distributed to U.S. Customs and Border Protection. Calls for the restructuring of the organization go back to the Iranian embassy hostage crisis when the INS could not tell how many Iranian students were present in the US, but it was not until 9/11 that the organization was finally restructured.

Other changes to immigration came also came with the new Presidents, George W. Bush of the United States and Vincente Fox of Mexico in the year 2000. Both presidents wanted to improve relations, especially through cooperation on immigration. When he was the governor of Texas, President Bush had supported expanded admission of the temporary workers program for Mexicans. President Fox also supported a legalization program for illegally resident Mexicans already in the United Sates. In his first visit outside the country with a foreign leader, President Bush went to visit President Fox at his ranch in Mexico to discuss U.S.-Mexico relations. They decided to create a high-level, bilateral group of officials to meet regularly to discuss the migration issue. Congress opposed this group, and after 9/11, they were able to easily slide the issue off of the agenda, and there were no real advancements on this issue during President Bush's first term (Castles 8-9). During his second term, President Bush again made immigration reform an new priority. However Congress found difficulty cooperating to pass a comprehensive reform bill, as both the House and the Senate each passed their own, excludable bills (Griswold 183). In 2006 a "compromise bill" was created, yet also failed to pass. When President Fox was replaced with the new Mexican President Calderon, who wished to downplay the role of immigration in U.S.-Mexico relations, joined with President Bush's declining popularity, the immigration issue became virtually off the table 
(Castles 9). As a result, the immigration reform remains a major issue that has been left unaddressed for years. Hopefully now with the uproar caused by the new Arizona Immigration Law, the immigration debate will be reopened, and this time, hopefully met with a new solution. 


\section{Chapter 6}

\section{IMMIGRATION AND ITS EFFECTS ON THE UNITED STATES ECONOMY: AN ECONOMIST PERSPECTIVE}

There has been much debate on whether increasing immigration to the United States is beneficial or damaging to Americans. Clearly it benefits those migrating to the United States, or else they would stay in Mexico, but how does it affect the native born? The clearest way to analyze an economic concern is through a economic tool called "cost/benefit analysis," where the gains are weighed against the costs to see which is greater. This technique will be used to determine if the country is overall better or worse from immigration. Public opinion alone is not a reliable tool for this measure. In the US, polls will show that opinion on immigration will fluctuate with the economy. When the economy is doing well, immigration is tolerated, but when the economy declines polls drop and the public seems to turn restrictionist (Pastor 131).

One of the more vocal criticisms of immigration is that it steals jobs from Americans. Immigrants are used to significantly lower wages in Mexico, and will thus accept lower wages than an American for jobs in the US. When the supply of Mexican labor is relatively abundant, employers may chose to hire more Mexicans for less cost than Americans who demand higher wages. Yet this trend is really only being seen in the low-skill job market, which effects a declining share of the American workforce (Griswold 191). In addition, lower wages paid to the low-skilled sectors of 
the economy in fact increases the general welfare of the rest of the population. By depressing prices for housing and food, even those in the low scale sector losing their jobs to immigrants gain some benefit from the decreasing costs of food and housing. Those who argue that immigrants are depressing wages can only be referring to the low skill sector, because by lowering prices on other products, immigrants raise the real wage of most Americans. When goods are cheaper, Americans get to keep more of their income (Griswold 198). Therefore if one looks at this issue on the whole, immigration raises wages for the majority and depresses them for the minority of Americans. Therefore without immigration, the majority would be worse off and the minority would be better off.

In economics there is a term used when describing trade between countries, including the trade of people in the case of immigration, called "comparative advantage." Though counter intuitive to many politicians, this phenomenon is well understood among economists and is taught as a basic concept in any macroeconomics course. This concept describes that every country has different sectors of production where it excels and has a lower opportunity cost to produce. In the same sense, countries also have goods that take more inputs per unit to produce than another country, and these goods would have a higher opportunity cost. The theory follows that if each country specialized and produced the goods for which they had the lowest opportunity cost, then traded the surplus of these goods with another country for goods with a higher opportunity cost, the country would gain a net surplus from this trade. When countries produce the goods they are most efficient at producing and encourage trade with these goods to gain the goods they are less efficient at producing, there will be less waste in the economy. In this model, all 
countries involved in this type of trade will gain from trade. The theory also holds that by opening up trade and allowing goods to flow freely between countries, this will facilitate the specialization process, increasing the gains from trade. Different inputs affect which goods are cheaper for a country to produce. For example, in the United States technology is more abundant, whereas in Mexico labor is more abundant. Therefore, if the US would like to keep industries that require high labor in the US instead of importing these goods from Mexico, then the US must import labor in order to maintain this comparative advantage. In conclusion, following the economic principle of comparative advantage, it would be most efficient and gains from trade would be greatest when the trade of goods and people is open between US and Mexico.

To continue the discussion of a cost/benefit analysis, another prominent argument is that Mexican immigrants are costing the United States millions by taking advantage of social works programs, like health care and education. What many fail to realize however is that illegal immigrants do not have access to programs like welfare, and even those legal immigrants who pay taxes have difficulty accessing the system as well. A key feature of the 1996 welfare reform legislation made access to welfare programs by noncitizens much more difficult. New permanent residents must now wait five years for eligibility for food stamps and Social Security insurance (Coates 92). In the case of welfare, this cost is highly exaggerated.

Though these migrants are not eligible for benefits, their children on the other hand, often do take advantage of these benefits. Children born here, whether to legal or illegal parents, acquire citizenship by nature of their birthplace. The Pew Research Center estimates that there are 1.8 million citizen children living in 
unauthorized families (Coates 94). These children become eligible for Medicaid and the State Children's Health Insurance Program (SCHIP), and as of 2005 these children participate in these programs slightly above fifty percent (Coates 93). These children also put pressure on the school systems, and this distribution is highly uneven with some states handling much of the burden.

However there is a counterweight to this burden. Many legal and even illegal immigrants pay taxes. Those here with false Social Security papers will contribute to the fund, and will never withdraw from it. The Social Security Administration estimates that the majority of the funds paid through names or numbers that do not match their records come from undocumented workers. By the end of 2005 those funds totaled $\$ 520$ billion. False papers will also require illegal immigrants to pay income tax to fund programs like Medicare, and as many as one half to two thirds of illegal immigrants end up paying this fee. In addition, all migrants whether legal or not pay sales tax, and sometimes property tax indirectly through rents. Finally, the commodities these immigrants help to produce will create additional sales taxes (Coates 94).

Unfortunately is difficult to perfectly calculate these costs and benefits, because it is difficult to separate the impact of immigrants from other factors affecting income and unemployment, and due to the illegality of some of their statuses. However the general consensus among economists is that overall, immigrants create net gains in the economy for American consumers, businesses, and GDP. An Oregon study in 2007 estimated that the net taxation from undocumented immigrant labor totaled between $\$ 231$ to $\$ 323$ million in Oregon. Note that this is in a state where undocumented workers are eligible for SCHIP, food stamps, or even temporary cash 
assistance (Coates 94). In 2006 a study by the Kenan Institute of Private Enterprise at the University of North Carolina at Chapel Hill found that the Hispanic immigrants in the state imposed a net cost of $\$ 61$ million, but improved the economy by $\$ 9$ billion (Griswold 198). Furthermore in Texas in 2006, the Texas Comptroller of Public Accounts calculated a cost of $\$ 1.4$ million resulting from undocumented workers in the state, but a net gain of $\$ 17.7$ billion (Griswold 198). These figures illustrate astounding net gains from immigration on the local economies of states. However, when looking at states along the border regions where there is the highest concentration of immigrants, results are more varied. Yet even if results could conclusively indicate that the net gains in these areas were negative, federally net gains from immigration are consistently positive. The Council of Economic Advisors to the President estimated the surplus from immigration in the national economy as $0.28 \%$ of US GDP, or roughly $\$ 37$ billion a year (Coates 95$)$. The Council reported that on average, US natives benefit from immigration, which is clearly evident through the statistics presented. Therefore in regards to states who are hit harder by immigration than by the rest of the nation, a federal policy to help those states struggling to accommodate the influx of immigrants would be beneficial for those states while maintaining a positive balance for the whole.

Thus it is clear that Mexican immigration is consistent with the clear economic logic provided. Immigration provides US businesses with the workers they want, when and where they want them. This modestly growing labor force allows the US market economy to produce a wider and more affordable array of goods and services for American households, raising the standards of living for the majority of American workers (Griswold 200). This further reinforces the idea of comparative 
advantage. As the US imports labor, the economy as a whole sees net benefits. Therefore, the opening of borders and the increase in specialization should be further encouraged through a more liberal immigration policy. By opening up the borders further, economic theory supports that gains would continue to increase. Despite rumors and myths to the contrary, most likely purported by the minority that is negatively affected by this movement, immigration will help expand and further develop the US economy, and should be both embraced and encouraged in future policy reforms. 


\section{Chapter 7}

\section{RECOMMENDATIONS FOR FUTURE IMMIGRATION POLICY REFORMS}

In order to fix the shortcomings of current US immigration policy, there are several policy prescriptions which hold promising results. The solutions described below address the gaps in immigration policy by reconceptualizing the way immigration policy is traditionally handled. The traditional way to understand immigration motivations is through push and pull factors. In the past, policies have mostly catered unevenly to pull factors, attempting to control the demand side of the equation without making serious efforts to cut off the supply side motivations. Therefore these policy changes recommend shifting policy focus from supply to demand by easing restrictions on demand or pull factors and concentrating more on the motivations or the push factors that drive Mexicans to the border.

First, US immigration policy must ease restrictions on demand. Many times policies failed because they underestimated these motivations for immigration. In these recommendations, motivations are regarded as constant in the short term, and as such a powerful force that those who may chose to enter the US would risk their life to do so. The recommendations assume that it does not matter to them whether or not they enter legally or illegally, just that they get in by using the path of least resistance in order to do so. Therefore if policy wishes to curtail illegal immigration, new policies should make it easier to enter the country legally than illegally. 
Second, addressing the supply of immigration is the next key piece of the puzzle. These recommendations recognize that if immigrants are so motivated to enter the US that risking their lives to do so, then the conditions in their home country must be pretty dismal. Therefore a new policy which addressed the hardships in Mexico and created a developmental aid program for the country would be extraordinarily beneficial for both parties. Investing in Mexico and creating developmental projects which focus on education, infrastructure, and credit would slowly transform the Mexican economy into one that attracted investors instead of one which repels its labor force. If Mexico were able to develop enough to lower the wage differential between the US and Mexico and provide a quality education to its citizens, many Mexicans would be thus more motivated to stay in Mexico than they would be to immigrate to the United States.

By opening US borders to legal immigration, accommodating demand and using it to their advantage, while at the same time controlling the push from Mexico, the US and Mexico will finally reach an immigration equilibrium that is mutually beneficial and easy to enforce.

\section{Loosening Restrictions on "Pull Factors"}

A Border Patrol veteran once said that Mexican immigration "can’t ever be stopped, just regulated" (Fukuyama 58). This is the central realization that this recommendation follows. This recommendation builds of the experience of previous policies like the bracero program, which showed that given the means to enter the country legally, immigrants will use this legal option over entering illegally. However without this alternative, immigrants will continue to enter the country, just without 
proper documents. Therefore in order to stop illegal immigration, legal alternatives must be offered, because the amount of money the US would otherwise have to spend in order to build a wall to keep out every single alien is both unrealistic and inefficient. Opening the borders to allow the natural flow of immigration is the US' best option. In order to achieve this measure, the future policy should be made simpler and easier to enforce, legal alternatives must be made more accessible, and these will be achieved through changes in policy and increased communication and cooperation with Mexico.

David Coates proposes that "complex problems," like immigration, "require complex solutions" (Coates 97). Yet this conclusion is incorrect. Creating complex solutions for already complex problems like immigration will only further complicate the issue. By creating simple, easy to enforce changes in policy, immigration laws will be easier to understand, follow, and enforce. Loopholes, categories, and graduated policies that create different rules for many different groups of immigrants only create confusion. In future policies there should be only two tracks for an immigrant, guest worker or citizenship. Both processes should be simplified.

The process of becoming a legal immigrant needs not to be made easier to attain, but made to be simpler to understand. Many Mexican immigrants can get lost in the paperwork, misunderstand a message and miss an important appointment, or end up running in circles looking for an answer to an important question. Therefore, either by redirecting federal funds from inefficient policies, a program should be created that would assign each candidate for naturalization with a "citizenship advisor." This advisor would ideally see the candidate through the entire process, from entry to naturalization. An immigrant would be required to register with their 
advisor upon arrival, and to meet with them regularly. This advisor would help see the immigrant through the process, answering any questions and making sure they were on track. Also if one of their advisees fell off the radar, the advisor would immediately know and be able to report this directly to the federal government law enforcement. This system would help keep better track of immigrants in the country and help naturalize those seeking citizenship with the least confusion and waste of resources.

Changes should also be made to make immigration policy more enforceable. A complicated system with loopholes would be unrealistic to enforce. Any time the federal government has been unable or unwilling to enforce policies, the burden falls mainly on the states most affected, causing hostility and impatience with immigrants. Immigration is a federal responsibility and needs to be properly enforced. Legislation making it unlawful to employ aliens, like the employer sanctions program from the IRCA of 1986, can be adjusted to be significantly more realistic and efficient. The previous weakness of the employer sanctions program was that it was improperly enforced by both the government and employers. Employers had difficulty verifying the legal status of immigrants, and since this difficulty was recognized by the government, enforcement was more lenient, thereby providing a loophole that dissolved incentives for employers to comply. By making a more efficient ID verification system that placed responsibility on employers, employers would be more careful when hiring their workers. The key here is to decrease the ambiguity in the "knowing" of whether an immigrant is legal or not. In addition, the penalties for hiring an illegal worker should be clear and should be enforced. Discounting 
punishments because the lawbreaker is a naturalized citizen is unfair and will only create inefficiency.

The identification system is the first step in improving enforcement. In 2007 the Bush Administration took a positive step in this direction by creating the "No-Match Letters." Through this program, Social Security numbers on W-2 forms that do not match up with the names and numbers in the Social Security records will be compiled and letters will be sent to employers to notify them of the discrepancy. Employers will then have 14-90 days to respond or they will receive a $\$ 10,000$ fine (Castles 184, Socialsecurity.gov). While this was a step in the right direction, it is not the most efficient solution. Since records are checked yearly, by hiring Hispanic workers employers will be taking the risk that they are not illegal, and that they will not be deported half way through the growing process. This would be harmful for employers and could lead to discrimination for workers.

Therefore, a better system would be to address the legality of a worker upon hire rather than a yearly notification. The IRCA already set the precedent for this in some regard. The IRCA mandated the employers must fill out an I-9 form for each new hire in order to prove the employee's eligibility. However, since there was not an adequate way to ensure the validity of these documents, the practice failed. Yet this policy was very useful in that it created a new habit for employers, one that is still used today. It is now a developed habit for employers to fill out a form and check the identification of new hires. With this routine already in place, future policies could build off of this rather than creating a new policy and teaching new behaviors. By simply strengthening the ability of employers to verify documents with a more accurate and minimally burdensome system, it would empower employers to better 
enforce a current practice, reducing the inefficiency that comes with teaching a new set of behaviors (Martin 161). This is a large task, but it would have high returns. Already the idea may be within reach. For over ten years, immigration agencies have been working on a computerized system to verify the documents a new hire presents. This mechanization, known as the Basic Pilot, holds huge potential and should be a project worthy of serious investment (Ibid). Computerized, reliable, and immediate verification would help tremendously lower the incidence of hiring illegal workers.

In addition, through this system the federal government takes some of the responsibility off of the shoulders of the employers. Ideally, the verification test would be a perfect indicator of legal status. However if there was a gap of information in the system, this would be the fault of the federal government and not the employer. If each employer uses the same system for verification, and if they system happened to have a mistake and the immigrant was they hired was illegal, it would not be the fault of the employer. The better this system is at identifying illegal immigrants, the less chance this will happen. Therefore it is simply the employer's responsibility to check each worker and to refrain from hiring the worker if his legal status is not confirmed. If the employer broke this rule, this would be a punishable offense. But either way, every future employee will be checked through the system and have their legal status verified before being hired, which will also reduce employer concerns that the person they train to work for them will not be forcibly removed from the country.

In order for this system to work properly, however, its provisions must be consistently enforced. Employers may find it profitable to hire illegal workers because they may accept a lower wage than legal workers. In order to curtail this phenomenon, without infringing upon the rights of employers with a system that 
allows federal agents to perform "surprise checks" on the employer's property, policy makers would be wise to implement an open guest worker system. If unlimited guest worker passes were granted, then the supply of illegal immigrants would fall drastically. Also if no minimum wage was set for this system, immigrants would not have to be illegal to be competitive. A system with these provisions would remove the supply and desire of employers to hire illegal immigrants.

\section{An Open Guest Worker Program.}

The idea of a temporary guest workers program was introduced in the 1952 Immigration and Nationality Act which authorized the H-2 program. The IRCA of 1986 split the $\mathrm{H}-2$ program into its current form of $\mathrm{H}-2 \mathrm{~A}$ for agricultural workers and $\mathrm{H}-2 \mathrm{~B}$ for non-agricultural labor. Both programs are administered by the Employment and Training Administration (ETA) of the U.S. Department of Labor (DOL) and U.S. Citizenship and Immigration Services (USCIS) of the Department of Homeland Security (DHS). The H-2A program allows for the temporary admission of foreign workers to the United States for seasonal agricultural work on the condition that there are no qualified US workers available at the time. In order for an employer to be eligible for H-2A workers, they must first apply to the DOL for certification. In order to be certified, employers must prove that there are not sufficient US workers available and that the hiring of $\mathrm{H}-2 \mathrm{~A}$ workers will not affect the working conditions for those US workers similarly employed (Eisenbrey 204). H-2b visa are similar to H$2 \mathrm{~A}$ visas except they are issued for non-agricultural workers. The H-2B visa program is the fastest growing visa program in the US (Eisenbrey 206). 
There are currently no annual limits issued for these visas, and that is exactly how it should be. This aspect of the program is crucial to the success of immigration policy reform. Though many argue for placing limits on these visas, experience has shown this will only increase illegal immigration, which runs contrary to the reason the program was created. If anything, the program should even be expanded farther. Though it is most highly politically improbable, taking out the protectionist certification would be even more beneficial for the economy overall and in reducing the incidence of illegal immigration. However, this program in its present form is one of the US' more adequate immigrant policies, and this clause does not seem to stop too many employers from gaining the workers they need. In 2007, the USCIS received 6,212 $\mathrm{H}-2 \mathrm{~A}$

Petitions and approved 6,134 petitions for 78,089 beneficiaries, and the DOL issued 50,791 H-2A visas (DHS). Therefore it seems that most employers were approved for at least some amount of labor, but evidence is lacking as to whether the amount of employees granted to each employer is the full amount requested.

Another note is that perhaps the visas should also be granted to the level which Mexican immigrants are demanding them as opposed to issuing them based solely on declared employer demand. If all immigrants who were eligible to work in the United States (eligibility depending on ability and criminal record) and applied to do so were given a visa, this would decrease the incidence of illegal immigration. Then immigrants could enter the country and be given the opportunity to find a job after they got there, as many illegal immigrants tend to do. These visas would then expire after a certain amount of time if the immigrant was not able to find a job. Since the majority of immigrants come to the United States for the sole purpose of obtaining 
a job, this should be a realistic expectation. When an immigrant receives a visa and activates it upon entering the United States, then this immigrant would be entered into a database. Once an immigrant receives a job and the employer sends in his or her I-9, this would be recorded. For those immigrants left without I-9's submitted after their visas expire, their name will go on a watch list, and appropriate enforcement measures would follow. This would hopefully reduce the incidence of immigrants staying in the United States after their visas expire. Finally, to increase efficiency these visas should be easily renewable. As long as the immigrant still has a job when it is time for the visa to be renewed, there is no reason for the immigrant not to be re-issued a new visa. Doing so would only place further limitations on the program, which is counterproductive.

Some argue that perhaps the guest worker program is not working because there are still illegal immigrants entering the US despite the lack of an annual limit. However this is because the guest worker system is not perfect, and changes can be made to make it more effective. An effective guest worker program must include the maximum amount of mobility and a minimal amount of red tape (Griswold 191). Instead of setting price minimums that force legal workers to compete with illegal workers, a better protection for guest workers would be the freedom to change jobs if pay or conditions are unsatisfactory. By giving workers mobility, the market will correct itself to give workers the desired results. The fatal flaw of the bracero program was that it tied workers too closely to employers, giving employers leverage to abuse their hired help. If the legal worker was unsatisfied with the conditions at his worksite, then the employer could simply deport him. With less red tape, in this situation the worker could simply find another employer who provided better working 
conditions (Griswold 191). This is also beneficial for the US, because workers can move to the areas where there is the most demand. For example, when the housing market went down, under this program workers could shift to retail or hospitality sectors (Griswold 191).

Another fear is that by making a more open immigration policy, which less restrictive guest worker program advocates, then this would increase the overall level of immigration in the Untied States. Scholars are generally split over this issue. Daniel Griswold argues that these fears are unfounded. He argues "legalization does not necessarily mean more immigrants entering the United States," instead the most likely consequence would be "the transportation of an illegal flow to a legal flow" (Griswold 189). This is because the amount of immigrants entering the country will naturally be capped by the employers' demand for these workers. Since immigrants come to the United States for higher wages and employment, if these options are no longer available, then there will be limited motivations for immigration.

Thus, an open and minimally restrictive guest workers policy is the key component to any batch of immigration reform measures. This policy would place labor where it is most efficiently needed, decreasing the incidence of illegal immigration, and perhaps even restoring the traditional circularity of Mexican migration which was broken in the 1980s (Griswold 189). By offering an accessible, legal alternative, immigrants will chose the legal option. Entering the country illegally has high costs, and therefore if it was made easier to enter the country legally, rationally immigrants would choose this option. Not only would it be less dangerous, but would also protect them in the future from a manipulative employer. With legal status, immigrants would not fear changing jobs or demanding better working 
conditions with the promise of a swift deportation. As a result, an open guest worker program is an essential piece of the immigration reform puzzle and should absolutely be included in future reforms.

\section{Shifting Focus to "Push" Factors}

On the other side of the reform process, increased efforts should be made to address the "push" motivations of immigration. Traditional immigration policy usually revolves around pull factors, factors that the US can directly control. Controlling immigration through push factors is less direct, but it is no less effective. Instead, addressing certain pull factors may be more effective because it addresses the root of the problem, underdevelopment in Mexico. The reason that so many Mexicans immigrate to the United States is to get a job, to get a higher paying job, for a higher standard of living, or for a better education for themselves and their families. If these

provisions were already provided in Mexico, then far fewer Mexicans would be motivated to move to the United States. Thus the argument for investment in development raising wages and increasing opportunities in Mexico will in the long run slow immigration to the United States. Development also has the added benefit that by increasing the overall welfare of a prominent trading partner, trade will be more profitable for both parties.

Investment in the development of Mexico is not a new idea. The Mexican president in the 1970s, Luis Echeverria spoke of this in his State of the Union Address. He proclaimed that farm workers need "access to a decent living in their own country" (Kiser 215). Echeverria argued that by fostering Mexico's economic and social development, this would increase opportunities for better wages and job opportunities 
(Kiser 196). US President Jimmy Carter also reflected these sentiments. In addition to a host of other recommendations, President Carter also suggested "strengthening Mexico's economy as a means of reducing the flow of labor in to the United States" (Kiser 130). Additionally, this was one of the founding ideas of NAFTA, that by giving Mexico preferred trade status, that would spark development and decrease immigration. In fact "virtually everyone agrees" that economic development in Mexico would help reduce immigration (Coates 110). Coates points out that "people do not leave the countries, culture, native languages, and families they know and love unless powerful incentives compel them to do so" (Coates 110). Mexicans would much rather stay in their home country, but many are forced to immigrate so that they can adequately support their families.

This leads to the discussion on how far Mexico must develop in order to significantly reduce the flow of immigration. While there are no exact estimates available, it is clear that wages would not need to match the United States exactly in order to have a significant impact on immigration (Pastor 52). Evidence exists for this trend in other areas of the globe. In Europe, Italian labor migration to northern Europe was high in the 1960s, but slow population growth, the rapid transformation of agriculture, and the Italian economic miracle created jobs and raised wages to a level where migration eventually slowed dramatically. Immigration slowed so dramatically that by the time the EU allowed for freedom of labor movement without restrictions, few chose this option (Bohning 1972, Martin 25). This phenomenon is true now throughout Europe. Though wages and job opportunities vary greatly between borders, with the income per capita gap between Greece and Germany reaching 1 to 4 , immigration to these areas of higher development is much more even. This European 
example as well as others in Asia provide support for the case of development stemming immigration.

Yet now the question remains as to the best way the United States could go about helping Mexico develop. One rather blunt example would be to directly take funds from inefficient immigration projects, like building a wall across the border, and to transfer them directly to developmental projects in Mexico (Sotelo 62, Coates 111). However, there is much debate as to whether this direct method is politically feasible.

Another less direct option would be to use NAFTA to facilitate investment in Mexico just as richer European countries used the European Union to invest in their own trading partners. The European Union used the structural funds project to "level the economic playing field" to invest in less developed areas (Miller 31). Italy, which served as a previous example in this paper, was a major beneficiary of these developmental investments. Italy used the funds for infrastructure developments, which benefited their overall economy, and these benefits rippled out into the rest of the European Community. The idea follows that if the United States and Canada were able to set up a similar fund for Mexico, this would further develop Mexico's economy and strengthen the overall trade alliance.

There are many ways this type of investment could produce results in Mexico. For example, like in Italy, investing in infrastructure would be a good starting point. Near the Mexico-U.S. border in Mexico the economy is booming. In the past five years, more than one million Mexicans moved to the border from the central and southern areas of Mexico because the factories located on the border region tend to pay more. However, upon arriving in the border region, many 
Mexicans save up enough money and then leave for the United States, where wages are even higher. As a result the annual turnover rate of labor in the border factories is close to one hundred percent (Pastor 137). If roads were built or improved from the border to the center or south of Mexico, investors would be able to move more easily to these locations, dispersing the greater economic sectors more evenly throughout Mexico (Pastor 138). This type of policy would bring more opportunities to the people rather than forcing people to constantly relocate in order to find better opportunities.

Using these funds to invest in education would also be greatly beneficial. In Europe, investment in rural community colleges inSpain and Portugal acted like magnets, attracting professionals from more advanced regions, and further distributing the influence and knowledge of these professionals into the wider rural community (Pastor 141). Education would raise the overall productivity level of workers in Mexico and also empower them to find better, higher skilled jobs within their country. Finally, investing in infant industries in Mexico may help those who were disproportionately affected by NAFTA (Coates 110). Many small corn farmers were driven out of business through trade with large US industrial farms. The intent is that by investing in growing industries, these resources lost with the implementation of NAFTA would be reallocated and used more efficiently with the help of a little push from the US and Canada.

Another alternative to NAFTA, or perhaps as a supplement to it, would be to facilitate and provide Mexico with greater access to lending and credit. In this way, Canada and the US would not be directly investing in Mexico, but rather helping them to help themselves by providing lower interest rates or a positive trade balance. 
Finally, investments in non-profit or non-governmental development organizations in Mexico would be another potential option to pursue. These developmental organizations often aid the poorest of the poor, working in rural regions to establish microloans and basic infrastructure to increase the community's basic standard of living. While evidence suggests that the poorest regions of Mexico produce little immigration, it is only by empowering all regions of the country that Mexico may fully develop and strive to reach its highest potential. Please see supplemental Appendix II for a Guatemalan case study on this developmental theory.

Ideally the end result of this package of policy recommendations would be not only a decrease in the flows of illegal immigration from Mexico to the United States, but also to create an environment where both the US and Mexico can reach their full economic potential. Mass legalizations, visa limits, and tight borders are all inefficient policies that yield counter-productive results. It is only by working with our neighbors to create the most efficient policies that the most beneficial solution for all will be achieved. 


\section{CONCLUSION}

Though illegal Mexican immigration to the United States is a difficult problem with many complexities, it is not an impossible issue to solve. The current and past policies that the United States have used to address this issue have provided a strong background knowledge of how immigrants will react to certain policies. Future policies should look adapt to this knowledge and constantly strive to achieve a more perfect solution. Though there is no silver bullet, one coverall policy that can fix this issue, there are many interwoven options and small changes that were outlined in this thesis which can comprehensively come together to create a current immigration climate that is more beneficial for both the United States and Mexico. In an increasingly globalized world, nothing happens in isolation. Policies that only address one side or one country in the problem will achieve little more than a partially effective solution. Only by analyzing and responding to motivations for migration from both the push and the pull perspectives can the most reasonable outcome be reached. Additionally, though some of these recommendations are a departure from previous policy, all work within the current system. None are radically outside the scope of possibility, nor do they suggest the creation of new institutions or the restructuring of current ones. These proposals simply offer small changes that can make a big impact. If followed, these recommendations will alter the immigration movement, moving it forward as a mutually beneficial and appreciated phenomenon, granting economic prosperity to the majority of Americans and empowering and supporting our Mexican neighbors. 


\section{WORKS CITED}

Ashbee, Edward, Helene Balslev. Clausen, and Carl Pedersen. The Politics, Economics, and Culture of Mexican-US Migration: Both Sides of the Border. New York: Palgrave Macmillan, 2007. Print.

Batalova, Jeanne. "Frequently Requested Statistics on Immigrants and Immigration in the United States." Migration Information Source. Oct. 2009. Web. 19 May 2010.

<http://www.migrationinformation.org/USFocus/display.cfm?ID=747\# 3>.

Bean, Frank D., Barry Edmonston, and Jeffrey S. Passel. Undocumented Migration to the United States: IRCA and the Experience of the 1980s. Santa Monica, CA: Rand, 1990. Print.

Castañeda, Alejandra. The Politics of Citizenship of Mexican Migrants. New York: LFB Scholarly Pub., 2006. Print.

Castles, Stephen, and Mark J. Miller. The Age of Migration: International Population Movements in the Modern World. 4th ed. New York: Guilford, 2009. Print.

Castles, Stephen. "The Factors That Make and Unmake Migration Politics." Rethinking Migration. New York: Berghahn, 2007. 29-61. Print.

Coates, David. "The Economic Impact of Immigration." Getting Immigration Right: What Every American Needs to Know. Washington, D.C.: Potomac, 2009. 83-96. Print.

Cornelius, Wayne A., and Jessa M. Lewis. Impacts of Border Enforcement on Mexican Migration: the View from Sending Communities. La Jolla, Calif.: Center for Comparative Immigration Studies, 2007. Print. 
Daniels, Roger. Guarding the Golden Door: American Immigration Policy and Immigrants since 1882. New York: Hill and Wang, 2004. Print.

Eisenbrey, Ross. "The H-2 Visa Programs: Real Need for Reform." Getting Immigration Right: What Every American Needs to Know. Washington, D.C.: Potomac, 2009. 201-18. Print.

Fukuyama, Francis. Illegal Immigration. San Diego, CA: Greenhaven, 1994. 46-54. Print.

Fuentes, J. "Impacts of U.S. Immigration Policies on Migration Behavior." Impacts of Border Enforcement on Mexican Migration: the View from Sending Communities. La Jolla, Calif.: Center for Comparative Immigration Studies, 2007. 55. Print

García, Juan Ramon. Operation Wetback: the Mass Deportation of Mexican Undocumented Workers in 1954. Westport, Conn.: Greenwood, 1980. Print.

Griswold, Daniel T. "Market-Based Solutions to Illegal Immigration." Getting Immigration Right: What Every American Needs to Know. Washington, D.C.: Potomac, 2009. 183- 200. Print.

Heer, David M. Undocumented Mexicans in the United States. Cambridge: Cambridge UP, 1990. Print.

Hondagneu-Sotelo, Pierrette. "Ten Things You Need to Know about Mexican Immigration." Getting Immigration Right: What Every American Needs to Know. Washington, D.C.: $\quad$ Potomac, 2009. 51-62. Print.

Kiser, George C., and Martha Woody Kiser. Mexican Workers in the United States: Historical and Political Perspectives. Albuquerque: University of New Mexico, 1979. Print.

Kposowa, Augustine J. The Impact of Immigration on the United States Economy. Lanham, Md.: University of America, 1998. Print.

LeMay, Michael C. Anatomy of a Public Policy: the Reform of Contemporary American Immigration Law. Westport, Conn.: Praeger, 1994. Print. 
Martin, David. "Eight Myths about Immigration Enforcement." Getting Immigration Right: What Every American Needs to Know. Washington, D.C.: Potomac, 2009. 149-70. Print.

Martin, Philip L. Trade and Migration: NAFTA and Agriculture. Washington, DC: Institute for International Economics, 1993. Print.

Martin, Phillip. "Trade and Migration: The Case of NAFTA." Development Strategy, Employment and Migration: Country Experiences. Paris: Organisation for Economic Co- $\quad$ operation and Development, 1996. 231-51. Print.

Massey, Douglas, and Chiara Capoferro. "Measuring Undocumented Migration." Rethinking Migration. New York: Berghahn, 2007. 257-84. Print.

Miller, Mark J. "Sketching Teh Age of Migration: Contextualizing the U.S.-Mexico Migration Impasse." Getting Immigration Right: What Every American Needs to Know. $\quad$ Washington, D.C.: Potomac, 2009. 15-32. Print.

Mills, Nicolaus, and Toni Morrison. Arguing Immigration: the Debate over the Changing Face of America. New York: Simon \& Schuster, 1994. Print.

Montwieler, Nancy Humel. The Immigration Reform Law of 1986: Analysis, Text, and Legislative History. Washington, D.C.: Bureau of National Affairs, 1987. Print.

Office of the Press Secretary. "DHS: Fact Sheet: H-2A Temporary Agricultural Worker Program." Department of Homeland Security| Preserving Our Freedoms, Protecting America. 6 Feb. 2008. Web. 18 May 2010. <http://www.dhs.gov/xnews/releases/pr_1202308216365.shtm>.

"Overview of Social Security Employer No-Match Letters Process." Social Security Online - The Official Website of the U.S. Social Security Administration. Web. 19 May 2010. <http://www.ssa.gov/legislation/nomatch2.htm>.

Passel, Jeffrey S. "A Portrait of Unauthorized Immigrants in the United States." Pew Hispanic Center. 14 Apr. 2009. Web. 19 May 2010. <http://pewhispanic.org/reports/report.php?ReportID=107>. 
Pastor, Robert A. Toward a North American Community: Lessons from the Old World for the New. Washington, DC: Institute for International Economics, 2001. Print.

Siavelis, Peter. "Beyond Push and Pull: Neoliberalism, NAFTA, Immigration Policy, and the Structural Incentives for Mexican Immigration." Getting Immigration Right: What Every American Needs to Know. Washington, D.C.: Potomac, 2009. 97-114. Print.

Stout, Robert Joe. Why Immigrants Come to America: Braceros, Indocumentados, and the Migra. Westport, Conn.: Praeger, 2008. Print.

"Three Decades of Mass Immigration: The Legacy of the 1965 Immigration Act."

Center for Immigration Studies. Sept. 1995. Web. 19 May 2010. <http://www.cis.org/articles/1995/back395.html>. 


\section{APPENDICES}




\section{APPENDIX I}

\section{The Individuality of Immigration: Experiences through Service Learning}

During the summer of 2009, I worked at a non-profit English as a Second Language (ESL) school for Mexican immigrants in the United States. While there, I also taught US Civics to those seeking US citizenship. I felt working here would give a face to my project and some much needed inspiration. However I found a lot more than I had expected while I was there. Not only did my students bring my project alive, but these people and their stories truly changed the entire way that I conceptualized my research. I feel I am in a unique position, because I was able to meet the people I was studying before I even cracked open a book. This immigration movement started out on a personal level for me, and whenever I read about a particular aspect of Mexican immigration, I would have a face to tie it to. I could not see this movement as a mass group of people, but as a very individual experience, which is exactly what it is and how it should be looked at. Hopefully by sharing my experiences at my worksite it will give the body of my thesis a much more personal experience as well.

In order to preserve the institution I worked in and the privacy of the people I taught, I will not include the name of the institution and I have altered the names of my students. They have given me permission to use their stories in my research, because I feel they are important, significant, and should be shared. These are people that I came to know very well. I worked at a location for adults, so they 
were all seventeen or older. These were some of the bravest and hardest working individuals I have ever had the pleasure of meeting. I hope to illustrate this through my retelling of their stories.

At the school I taught both the morning and evening classes, each two hours in length. Students typically went to one of the classes, but some went to both morning and evening classes, which totals to four hours of English lessons. This was on top of their work schedules and taking care of their families. Their abilities ranged greatly. Some had just walked in the door to the school that day and didn't even know the colors in English, and others were nearly fluent and were trying to fine tune their English abilities. Since I spoke no Spanish outside of "hola," I relied on my students who were nearly fluent to help me with teaching the beginning students. They also enjoyed teaching me Spanish words throughout our lessons, so we all ended up teaching each other while we were there. They all told me that they preferred that I didn't speak Spanish, because it forced them to think about and listen to the lessons in English, something they did not have the opportunity to do with their previous Spanish speaking instructor.

The amount of students ranged from day to day between from five and thirty students. During these smaller class days, I had the opportunity to sit and talk to my students about their own lives and experiences, both in Mexico and in the United States. One woman loved to tell me about her job, she owned and ran a Mexican food store. She was very proud of her store and its success. She had come to the United States in order to take advantage of the economic opportunities available here, and she had succeeded. 
Many students also talked fondly of their homes in Mexico, of the beauty they enjoyed living in rural Mexico. A beginning student used pictures to illustrate where he had lived, right next to a volcano and the ocean. Yet all of the students also described the poverty they lived in while they were there. Several students described how there were so few jobs available to them, that infrastructure was lacking and roads were cracked and broken, and compared it to the United States where people could buy nice clothes and cars. Many explained they had come to the United States not only to find work, but also to have an opportunity to enjoy more luxuries, which to them was a clean polo shirt and a car made in this decade.

Others had different reasons for making the journey to the United States. One man, Orlando, had come to the United States in the hopes of one day being able to provide a better life for his son. Orlando had to leave his wife and son and sell the small clothing company he had owned and built to come to the United States in order to attain citizenship. Once he received his citizenship, he would bring his wife and son to the United States to live with him. He wanted his son to be able to be educated in the United States school system to learn English. Orlando himself also wanted to learn English. His intelligence was apparent while speaking with him, and he was able to complete and understand lessons quickly. Though he owned his own business in Mexico, the only job he was able to find in the United States was in landscaping. An intelligent man with business experience not being able to find higher skilled work showed me the importance of speaking English in the United States. Yet even these low skill jobs provided a higher salary than many jobs in Mexico, simply because the American dollar is worth so much more. This also reversed my assumptions on why Mexican immigrants only worked in low skill jobs. It is not necessarily a lack of 
education in trades, but a lack of knowledge of English and the American job system. Perhaps those who learned English and had access to a job placement center, which taught them how to write a resume and placed them in a higher skilled job, may be able to find higher skilled work.

These students were not lazy, they were some of the most dedicated and hardest working people I have ever met. Those students who came to both sessions, who studied English four hours a day and had a full time job truly impressed me. Some had to come late to class after they had finished work, some with grass stains from their landscaping jobs. I was so impressed that after a day of hard work outside in the sun, these students came to evening English lessons instead of going home and taking some much needed rest and relaxation. Another Columbian woman had to leave classes early some mornings because of back pain from sitting in a chair. She had severely injured her back while working at her job moving boxes, yet she could not afford the necessary health care to fix the problem. I would also like to stress how it is very difficult for older students to learn a new language. Despite all of their hard work, learning English at age forty is a very slow process, and it takes an incredible amount of patience and determination. Some students get frustrated, learn a basic level of English and then do not come back to the ESL school. Yet there are others who are nearly fluent, yet continue to come everyday in order to practice and fine tune their English speaking and writing skills. Also the US Civics lessons are also a challenge. The questions that simply require memorization are easy, like who is the current US President. Yet explaining and understanding the balance of power between the three branches of government is much more conceptual and difficult to understand. 
I feel that many of these students earn a poor reputation because of the nature of their entry into the United States. Though not all had come to the United States illegally, near the end of the summer, many of the students who had entered illegally felt comfortable enough with me to share their stories. Several students entered illegally because they found difficulty either filling out, finding, or getting proper advisement on filling out the necessary paperwork needed to gain legal entry into the United States. Paperwork in general seemed to be an obstacle for many students for these reasons, even while in the United States. Another woman missed her interview with an immigration officer because of a miscommunication. She was receiving help in the process from a volunteer, and she thought the volunteer had told her she did not need to go to this meeting. As a result, she had to wait another several months to be eligible for her citizenship.

Of my students who had entered illegally, most had received the necessary paperwork once they arrived in the United States and are now legal residents with green cards and working visas. One woman followed her husband this way. Both crossed illegally and then attained working visas once they arrived. Another man, Orlando, did not want to leave his family for five years while earning his permanent residency, and actually left the country illegally. During an immigrant's permanent residency period, they must stay in the country continuously for five years. Orlando snuck across the border to Tijuana and flew home to his family after establishing permanent residency. Then five years later he snuck back into the country, as if he had never left, in order to be eligible for and to gain US citizenship.

Perhaps my favorite story of illegal entry was told by my student Alejandro. Alejandro was a younger student, only seventeen and living with his 
extended family in Delaware. He came to the United States at the insistence of his father, and crossed illegally with his uncle, in order to gain an American education and to learn English. He explained that English where he lived in Mexico was not taught well. It was simply taught through memorization of passages and vocabulary words with picture flashcards. There was little emphasis on grammar or sentence formation. During one evening class while studying different types of transportation, I asked Alejandro how he had traveled to the United States. I asked if he had traveled by plane, by bus or car, or by boat. He chuckled and replied, "I walked." He then began to tell me the story of his journey to the US. He explained how he walked across the dessert and snuck through the border, then bought a bus ride from Arizona to Delaware, where his extended family was living. This is a common trend in immigration, for groups of people to follow their family or friends when they immigrate. Alejandro followed this trend. He left his immediate family, his home, and his country and culture in order to find a better education living with his cousins, and he did this all when he was only fourteen years old.

To be clear, my experiences at the ESL school should be viewed as a micro-study of the movement, and only exemplify a small fraction of the Mexican immigrant population in the United States. Yet it is important because of what it does provide. The research in this work should be viewed as a supplement to the movement, and should not define the movement itself. Mexican immigration to the US, though defined as a movement, is very individual. Although there are trends within the movement, each immigrant has their own story and their own experience. Since this movement is so large, and their experiences are so varied, it is impossible to make sweeping generalizations. These people are all unique and act individually, and 
it is very important not to lose sight of this through analysis of the movement and when proposing policy changes to control it. 


\section{APPENDIX II}

\section{Partner's In Development, a Case Study}

\section{Service Trip to Guatemala}

In January 2010, I traveled with a group of students from the University of Delaware to San Bernardino, Guatemala. There the fifteen of us worked together with a small non-profit, non governmental organization called Partners in Development. PID first started in Haiti, and a second project was later developed in Guatemala. The name itself speaks volumes about the organization. This organization leads through empowerment, by partnering and working with communities to help them develop and prosper. The organization provides a child sponsorship program, a microloan program, helps teach English in local schools, and constructs bathrooms, homes, clinics and water filters for the community members. PID also manages to conduct these projects in a sustainable way, so that if PID had to leave the community would continue to grow. Homes are not built and then given to families, rather the families must first establish credit through smaller loans, and then are able to take out a larger loan to build the homes. These homes can be built at such a low cost because they are built with labor from the community as well as outside volunteers like our group of students. 
Through PID, our group helped build these houses, bathrooms, water filters, while teaching children's programs at the local school. On the weekends our group traveled to other small villages in Guatemala, and the differences in development between those villages empowered by PID and those who were not was striking. In the little village sponsored by PID, we witnessed the remarkable health benefits to the community members through the bathrooms, homes, water filters, and clinics. Bathrooms and clean water provide basic sanitation and can help reduce the incidence of parasites, while homes provide sturdier shelter from the elements. Families with children with health problems like asthma benefit greatly from having a dry, cool place to live and sleep.

These homes also provide unseen benefits like community pride. One woman burst into tears while describing the changes she has felt in her community, watching her neighbors attitudes bloom with optimism when provided their own home to take care of. The program leaders also described how the kids were benefiting from the project, not only in school, but also by the increased presence of foreign students in their village. Our presence was seen as a good way to expose the children to English and to the world outside of their little village in Guatemala. The whole community was given a better impression of Western culture when they saw us, whom they considered millionaires, digging in trenches and mixing cement with rusting shovels to help build them a home.

Through this project it became clear to me that for many developing communities, all that is needed is a little extra capital to give the community the kick 
start it needs to truly take off. I witnessed community members do wonderful things with their loans, including starting their own small restaurant in the community. Empowering the people, allowing them to create their own businesses to improve their own standards of living was truly remarkable, and should be a model to follow. If other communities were also given this opportunity, I have no doubt that they would also thrive an flourish as did the little village in San Bernardino, Guatemala.

\section{Interview with Gale Hull, President of Partner's In Development, April 2010}

Although this organization does not speak for or to the successes of all small developmental organizations, it offers an eye opening case study of the benefits and potential that these organizations may provide. Below is an interview conducted with the President of the organization, Gale Hull, who I had the privilege of spending time with on my trip to Guatemala. Though she travels regularly from Haiti to Guatemala to the US, her schedule coincided with ours and our group was able to meet her in Guatemala. Though we had many conversations in the evenings after a long day of work, I emailed her the following questions on our return from Guatemala, indicated by "Q." Her answers in response are indicated by "A."

Q: What inspired you to start the child sponsorship program in Haiti?

A: We started the child sponsorship program as a response to a trip to Haiti when we saw so many starving children. 
Q: What drove you to keep the project going, to develop it further, and to start up in Guatemala?

A: The program in Haiti was very successful but Haiti had a lot of challenges. As an organization we had a goal to add another country.

Q: If you could estimate, how many lives do you feel you have touched as a result of the work through PID?

A: I think that is difficult to guess how many lives are touched by the work of PID but in our programs in Haiti and Guatemala we felt that until the earthquake our programs reached about 10000 people. Since the earthquake however we have seen 17000 in our clinic in Haiti alone.

Q: Do you have any end goals for this project? Or are you more following it wherever it takes you?

A: We always struggle with how big to grow. I feel that small programs really are more in touch with the people and can see needs more clearly than larger organizations who have to be less personal. So far we have been able to follow the need so it hasn't been an issue.

Q: Would you mind telling me a bit more about the small business loans program? Also, how have you seen this program improve the lives of those who have used it? In general has it been successful?

A: The small business program started in Haiti because the parents of the kids we had in the program told us," we are so grateful for all you have given us but we would like to be able to support our own families. Can you help us to start 
businesses?" The program is set up in groups and each group sets up the parameters for their groups: how often they pay, what the savings rate is. Our goal was to increase the families' income by $\$ 30$ US dollars a month so that we could be assured that they could be able to eat everyday. In general we feel it is successful. Some of the people are excellent business people and actually have gone way beyond our expectations. We call them the fortune 500 group. Others do just okay but it gives them a boost.

Q: When I was in Guatemala I noticed that the house building projects had other side benefits besides just a place to live. The homes provided health benefits by escaping the weather, sanitation benefits from the bathrooms PID built, and even a sense of pride for the owners. Could you comment on any other effects you have noticed, and how these effects have helped further develop the community?

A: We have noticed that once people move into their houses, the rate of illness decreases by about $50 \%$. When less people are sick they begin to improve economically as they can work more days out of the week. They are also able to have electricity so it increase ability for kids to do school work after dark. They begin to accumulate other items that improve quality of life and productivity.

Q: You have been with PID since the beginning. Looking back, how far do you feel the Conception village and community has grown and developed as a result of PID? Can you comment on the impact made by physically being in the host country and working directly with the population to organize development and its advantages/disadvantages over simply donating funds to a larger developmental organization? 
A: Because we have been located in one village we can see many changes. The school population has gone from less than 300 to over 450 . We repaired the school making it more secure and put a roof on it. We help to put up a school and repair the roof of another school. WE have seen health changes because we can monitor on a local level through the clinic. We can tailor the program to meet the needs instead of having to make need to fit the program. We noticed that many larger organizations are too far away to identify the need. It can be difficult to be in such a close relationship with those you serve.

Q: Does PID receive any federal funding? What do you feel you could do if you were granted some or more funding? How would you expand the program further?

A: PID does not receive federal funding. Most of our donations come from individuals. The rate of growth has been slow but steady and has given us the freedom to develop our programs as we grow. We have a model now that we feel works and more money would help us to deliver it to more people. 